\author{
ROBERT J. FLANAGAN \\ Stanford University
}

\title{
Wage Interdependence in Unionized Labor Markets
}

SOME THIRTY-FIVE years after the major growth in unions in the United States, the literature on inflation reveals no consensus over the role of collective bargaining in wage inflation. The contrast between the ambivalence of the professional literature toward union influence and the concern of policy officials with the development of negotiated wages seems particularly acute during the biennial and triennial renegotiations of labor contracts in important industries. Most nonprofessional observers of these "wage rounds" would be surprised to learn that they apparently lead no life of their own in many wage-adjustment models.

The lack of explicit attention to union activity in many models usually rests on one of two standard justifications. First, unlike those in other industrialized nations, labor unions in the United States represent a relatively small fraction of the labor force, leading some authors to assume that events in the organized sector would have little effect on the general level of money wages. Second, standard formulations of price theory predict that unions that succeed in monopolizing labor supply will achieve a once-and-for-all relative-wage advantage but will have no long-term inflationary influence. Therefore, changes in the degree of labor market monopoly will influence the rate of wage inflation, but unions should not exert an independent influence once that degree becomes stable. (Even

Note: I am grateful to the Graduate School of Business, Stanford University, for research support, to Diane G. Bayless of the Bureau of Labor Statistics for assistance in providing and interpreting some of the data, to Wayne Ferson for research assistance, and to members of the Brookings panel for useful comments. 
these formulations implicitly assume rigidity of nonunion wages in the face of an increase in the supply of labor to the nonunion sector that should result from reduced employment opportunities in the union sector.) In fact, several previous studies have reported a positive relation between the rate of change of money wages and changes in trade union membership (a purported proxy for union militancy) in both the United Kingdom and the United States. ${ }^{1}$

Taken at face value, this argument seems to justify neglect of the role of collective bargaining in postwar inflation in the United States, for the extent of unionization has been quite stable over this period. The main dynamic element has been the spread of unionization among public employees, which has essentially offset a relative decline in the private sector, where employment has grown most rapidly in occupations and geographic areas that are not traditional bastions of union strength.

An alternate view holds that the impact of collective bargaining settlements extends well beyond their own immediate domains as wage increases in one sector are emulated by workers elsewhere. The purported importance of institutional wage interdependence receives particular emphasis when, as in 1976, there is a round of highly visible negotiations in major industries. Given their coverage, these settlements are unlikely to be of serious policy concern by themselves. (In 1976, for example, contracts resulting from major collective bargaining negotiations established terms and conditions of employment for 4.4 million workers, or 5 percent of total nonagricultural employment.) Therefore, it must be the potential role of these settlements in the formation of wage expectations by workers in other sectors that is at the root of policy concern and certain appli-

1. A. G. Hines, "Trade Unions and Wage Inflation in the United Kingdom, 18931961," Review of Economic Studies, vol. 31 (October 1964), pp. 221-52; A. G. Hines, "Wage Inflation in the United Kingdom, 1948-62: A Disaggregated Study," Economic Journal, vol. 79 (March 1969), pp. 66-89; O. C. Ashenfelter, G. E. Johnson, and J. H. Pencavel, "Trade Unions and the Rate of Change of Money Wages in United States Manufacturing Industry," Review of Economic Studies, vol. 39 (January 1972), pp. 27-54. These studies are consistent with those of the influence of unions on relative wages, which conclude that most unions establish a relative-wage advantage over the nonunion sector shortly after organizing the relevant labor force. Although this markup fluctuates cyclically, there normally is no secular trend in the union-nonunion differential. The standard reference is H. G. Lewis, Unionism and Relative Wages in the United States: An Empirical Inquiry (University of Chicago Press, 1963). 
cations of incomes policy. ${ }^{2}$ Increases in "key" wages may be imitated in other negotiations within the organized sector. Moreover, labor economists have recognized that "threat" and "morale" effects may induce wage spillovers to the nonunion sector..$^{3}$ Clearly, if contagion to the nonunion sector is widespread, the potential for union influence on movements in the general level of money wages is greater than the simple statistics on unionization suggest. Threat effects, however, may be more likely during periods with more aggressive union organizing than has characterized the private sector in the United States in the past twenty years.

The extent of imitation of contractual wages is of interest for several reasons. First, if wage contagion is pervasive, the allocative role of wages in the economy may be substantially reduced. Collective bargaining may prevent the emergence of wage differentials that are necessary for the prompt reallocation of labor from one industry to another. A second and related issue involves the limitations on standard macroeconomic policies implied by a labor market in which contagion dominates wage determination. If current changes in union wages in sector $i$ are influenced by past wage changes in sector $j$ as well as by current market conditions in sector $i$, the responsiveness of negotiated wages to changing market conditions (the targets of standard monetary and fiscal policy) may be greatly reduced, or the response may operate with long lags. This insulation of wages from standard policy may be deepened to the extent that the key bargains or wage leaders involve long-term agreements. Even if currently negotiated wage changes were responsive to market conditions, they would tend to be dominated by deferred increases from contracts negotiated in earlier years. In the face of extreme contagion, there may be a case for auxiliary policies. Knowing whether wage contagion has reached the epidemic stage can be important in designing and assessing the potential role of policies or structural reform of the industrial relations system.

2. For example, it is widely believed that some form of pattern following dominates wage determination in durable-goods manufacturing, and this belief has formed the basis for some models of wage determination. See Otto Eckstein and Thomas A. Wilson, "The Determination of Money Wages in American Industry," Quarterly Journal of Economics, vol. 76 (August 1962), pp. 379-414. However, these studies have generally asserted rather than tested for the existence of wage imitation within a particular group of industries. Moreover, they assume that contract renegotiations are clustered in time, and this has become less true over the postwar period.

3. For one formulation, see S. Rosen, "Trade Union Power, Threat Effects and the Extent of Organization," Review of Economic Studies, vol. 36 (April 1969), pp. 185-96. 
This paper examines the issue of the interdependence of negotiated wages in the United States, and analyzes wage interactions between the union and nonunion sectors. It departs, therefore, from previous studies in certain respects. Most important, wage interdependence is viewed from the perspective of labor markets as defined by contractual relationships. Studies of aggregate changes in earnings, particularly those that are mute on the role of unions, obscure important differences in the process of wage adjustment under different market structures or contractual arrangements. This treatment conflicts with the disaggregations emphasized in some modern theories of inflation. ${ }^{4}$

Some earlier studies have examined wage interdependence among geographic labor markets, focusing on the role of potential migration in the pattern of wage change across regions. Others have tested for interindustry wage spillovers. ${ }^{5}$ The former rely on more or less competitive processes and do not consider contractual relationships, which frequently cut across the geographic boundaries by which data are organized. The latter may reflect contractual relationships, but suffer because in using earnings data, they combine wage adjustments in the union and the nonunion sectors although the differences in the contractual relationships are generally so great that the wage-adjustment process for the two could differ substantially. Moreover, the use of earnings data combines movements in contractual wages and wage drift. The analysis in this paper is confined to the former class of adjustments.

The subsequent sections pursue the issue of wage interdependence. First, the pressures for imitation are briefly reviewed, and an extreme view of the spillover process-that all wage changes are the same-is assessed by a comparison of the distributions of wage change for union and nonunion workers. This is followed by regression analyses of interactions between union and nonunion wage changes, which include an assessment of the impact of the Nixon administration's incomes policy on union and

4. See Arthur M. Okun, "Inflation: Its Mechanics and Welfare Costs," BPEA, 2:1975, pp. 351-90; John Hicks, The Crisis in Keynesian Economics (Basic Books, 1975).

5. See particularly Frank Brechling, "Wage Inflation and the Structure of Regional Unemployment," Journal of Money, Credit and Banking, vol. 5 (February 1973, pt. 2), pp. 355-79; and Lester D. Taylor, Stephen J. Turnovsky, and Thomas A. Wilson, The Inflationary Process in North American Manufacturing (University of Toronto, Institute for the Quantitative Analysis of Social and Economic Policy, 1972). 
nonunion wages. The final section tests for wage interdependence among several major labor contracts.

\section{How Similar Are Wage Changes?}

In the literature on industrial relations, discussions of movements in union wages have long emphasized the role of "custom" or "coercive comparisons" in maintaining stable relative wages among various skills, occupations, and industries. However, the focus on wage developments in the unionized sectors has obscured the role of wage imitation in unorganized markets. Wage similarity among firms competing in the same product and labor markets is no less than what economic theory predicts. An employer can, of course, postpone wage adjustments until the market signals that his wage is higher or lower than desired (for example, by an increase in the applicant or quit rate). However, a firm may find it cheaper to maintain its relative position by imitating the wage changes in "reference" firms in the relevant product and labor markets. This is the behavior underlying equilibrium-wage movements in many job-search models; empirically, it explains why many nonunion firms subscribe to and participate in wage surveys of their industry. Among many nonunion firms, wage imitation and the resulting wage pattern simply economize on personnel costs. $^{6}$

On the union side, the motivations are more complicated. The union leadership is presumed to gain utility from both higher wages and more employment of the membership. Under this formulation, union leaders may, to the extent necessary to preserve union membership, share the employer's perspective on the appropriate range of wage comparisons. The rank and file, however, is likely to emphasize traditional wage relationships in the development of bargaining positions. The perspective of the rank and file follows from a straightforward consideration of losses and gains under alternative bargaining strategies. Most members will gain from the maintenance of traditional wage differentials if this justifies increasing wages; only a few will lose their jobs from subsequent adjust-

6. For an early development of this point, see M. W. Reder, "The Theory of Union Wage Policy," Review of Economics and Statistics, vol. 34 (February 1952), pp. 34-45. For some evidence on wage patterns among nonunion firms, see Lloyd G. Reynolds, The Structure of Labor Markets: Wages and Labor Mobility in Theory and Practice (Harper, 1951). 
ments in employment. Since layoffs are governed by seniority arrangements under most union contracts, it is clear who is at risk, and the rank and file have no difficulty in deciding where their bargaining interest lies. Union leaders who stray too far from their objectives in bargaining risk nonratification of the contract and ultimately loss of office. Moreover, the bargaining goals of the rank and file have presumably received greater weight since the passage in 1959 of the Landrum-Griffin Act, which provides for federal supervision of rerun elections of union officers in situations in which election irregularities have been proved.

Clearly, the problems and possibilities of wage distortion in a system of wage imitation or pattern following develop only when employers and unions form different wage references and when the union dominates in bargaining. Even in the unionized sector, institutional arrangements are sufficiently diverse that rigid wage imitation is difficult. The influence of market forces should be even greater in the nonunion sector. Yet some discussions of wage determination come close to maintaining that once wages are settled in a few key sectors, wage changes are largely determined for the rest of the economy. In this section, the merit of this rigid (naive) hypothesis of wage interdependence is assessed by examining data on the dispersion of wage changes in the union and nonunion sectors of manufacturing. In subsequent sections, less stringent wage-imitation hypotheses will be examined.

Only one source appears to provide separate time series of union and nonunion wage changes in the United States. The wage series are a product of the survey, Wage Developments in Manufacturing, of the U.S. Bureau of Labor Statistics. The data, restricted to total manufacturing, are published annually in the Bureau's Current Wage Developments. The union wage changes are obtained from data for major collective bargaining agreements (covering at least 1,000 workers) and a sample of smaller union establishments. The nonunion data cover general wage increases in a sample of nonunion establishments, which give either general increases alone or a combination of general and merit increases. Thus, for some firms in the sample, the omission of merit increases means that the data understate total wage changes. Establishments that grant merit increases only or that adjust wages on an individual basis are not included. ${ }^{7}$

7. The weighted average of union and nonunion wage changes in the survey, Wage Developments in Manufacturing, typically falls below the rate of change of hourly earnings (adjusted for overtime and interindustry employment shifts). In- 
Table 1. Coefficient of Variation and Standard Deviation of Effective Annual Percentage Wage Changes for Union and Nonunion Workers in Manufacturing, 1961-75

\begin{tabular}{cccccc}
\hline & \multicolumn{2}{c}{ Union } & & \multicolumn{2}{c}{ Nonunion } \\
\cline { 2 - 3 } \cline { 5 - 6 } Period & $\begin{array}{c}\text { Coefficient of } \\
\text { variation }\end{array}$ & $\begin{array}{c}\text { Standard } \\
\text { deviation }\end{array}$ & & $\begin{array}{c}\text { Coefficient of } \\
\text { variation }\end{array}$ & $\begin{array}{c}\text { Standard } \\
\text { deviation }\end{array}$ \\
\hline $1961-63$ & 0.732 & 1.843 & & 1.101 & 2.560 \\
$1964-66$ & 0.536 & 1.495 & & 0.571 & 1.786 \\
$1967-69$ & 0.441 & 2.125 & & 0.495 & 2.328 \\
$1970-72$ & 0.412 & 2.603 & & 0.528 & 2.293 \\
$1973-75$ & 0.364 & 2.823 & & 0.432 & 2.811 \\
\hline
\end{tabular}

Sources: 1960-63, U.S. Bureau of Labor Statistics, "Summary Release: Wage Developments in Manufacturing, 1960" (October 1961), and ibid., "1961," “1962," “1963" (September 1962, November 1963, and December 1964, respectively); 1964-68, John Kinyon, "A Report on Wage Developments in Manufacturing, 1968," Monthly Labor Review, vol. 92 (August 1969), pp. 33-39; 1969-75, Bureau of Labor Statistics, Current Wage Developments, annual article in relevant volumes.

a. Effective wage is defined as current wage plus deferred wage increase, plus cost-of-living increase.

These data have an important bearing on the naive wage-interdependence hypothesis. If pattern following dominates wage determination within the union sector but "threat" influences (spillovers to the nonunion sector) are weak, the dispersion of wage adjustments should be smaller for organized workers than for unorganized workers. Unfortunately, the data are too thin to provide a conclusive test of wage interactions between the union and nonunion sectors or between union settlements in manufacturing and nonmanufacturing, or of a less rigid wage interdependence among unions within the manufacturing sector. These topics are pursued in subsequent sections.

The distribution of effective annual wage changes by union affiliation appears in table $1 .^{8}$ Since most unions in manufacturing are not free to adjust their wages annually (except via predetermined deferred increases) and because the loading of wage increases over the contract period may

creases in earnings above contractual wage-rate changes in the union sector-the wage-drift factor-are one source of the gap. Furthermore, as noted in the text, nonunion wage changes are understated to an unknown extent in the data in Wage Developments in Manufacturing since the survey does not record merit increases that are granted in addition to general wage increases in nonunion firms. See Diane $\mathbf{C}$. Bayless, "Union and Nonunion Workers in Manufacturing Received Record Wage Gains in 1974," Current Wage Developments, vol. 27 (July 1975), p. 51.

8. Effective wage changes include cost-of-living increases, deferred wage increases from agreements reached in earlier years, and current wage decisions. The deferred component is relatively unimportant in the nonunion sector. 
vary, three-year averages are presented. The table reveals the inadequacy of the naive version of rigid wage interdependence. In the data underlying these computations, union workers received wage increases amounting to as little as zero and as much as 10 percent in the early years of the period and, more recently, ranging from zero to over 13 percent. While this hardly rules out spillovers, it pretty well undermines the view that current wage adjustments among organized workers play the rigid game of follow the leader that characterized a few wage rounds early in the postwar years. ${ }^{9}$

The coefficients of variation in table 1 also show that the dispersion of nonunion wage changes in manufacturing around the median wage increase exceeds the dispersion of union wage changes-a finding that is consistent with greater wage interdependence among groups of unionized workers, although the test is hardly a strong one. (A comparison of the two dispersion measures in table 1 indicates that the growth in the median wage increase over the period is responsible for the marked decline in the coefficient of variation.) Closer scrutiny of the underlying data reveals that virtually all the difference is due to the greater frequency of zero increases in the nonunion sector in most years. This frequency is quite sensitive cyclically. Thus, the percent of nonunion workers receiving positive wage changes rose from a low of 54 in 1961 (the union figure was 83.3) to a high of 90.1 in 1973 (when the union figure was 95.9). When workers receiving no wage change are ignored in the computations, the dispersion of wage increases is generally somewhat greater in the union sector. ${ }^{10}$

9. This conclusion holds if one focuses instead on absolute wage changes or wage and benefit changes. It also corresponds with early case studies of wage settlements within the jurisdiction of major unions. Indeed, the most interesting finding of the literature on wage contagion in the fifties was the apparent fragility of wage patterns. Even within the jurisdiction of the United Automobile Workers or the United Steelworkers, wages typically deviated from the pattern in response to unfavorable economic conditions. However, these deviations occurred only in the smaller plants and deviations were more frequent in fringe benefits and work-rule enforcement than in wages. Harold M. Levinson, "Pattern Bargaining: A Case Study of the Automobile Workers," Quarterly Journal of Economics, vol. 74 (May 1960), pp. 296-317; and George Seltzer, "Pattern Bargaining and the United Steelworkers," Journal of Political Economy, vol. 59 (August 1951), pp. 319-31.

10. For the record, downward wage flexibility is virtually unheard of in employment contracts in either sector. Even in the economic doldrums of the early sixties, general wage decreases were never experienced by more than 0.1 percent of union workers and 0.4 percent of nonunion workers in any year. These data (from the 
The results of this section are easily summarized. The naive wage-interdependence hypothesis of thoroughgoing imitation fails decidedly as a description of wage determination in both the union and the nonunion sectors of manufacturing. While students of labor markets have long recognized that strong tendencies toward imitation in the determination of official job rates are consistent with significant interfirm and interindustry variation in the rate of change of actual earnings (via wage drift), the data reviewed in the section show that even changes in negotiated union wage rates exhibit significant variation and in some years do not differ substantially from the dispersion of changes in nonunion wages. If contagion occurs, it apparently does not reach epidemic proportions.

Nevertheless, this version of the contagion hypothesis could well be regarded as a caricature of institutional wage interdependencies. It does not rule out some less stringent form of wage influence among groups of union workers. In fact, the somewhat lower and less cyclically sensitive dispersion in the organized sector suggests some role for alternative hypotheses of wage interdependence. Nor do the findings rule out the possibility that, for a given dispersion, the size of money-wage changes in these sectors is subject to wage developments elsewhere. These possibilities are examined below.

\section{Spillovers among Major Sectors}

Since the spread of unionization in the late thirties and early forties, it has often been assumed that movements in union wages are relatively insulated from labor market pressure and hence from the influence of macroeconomic policy. Although some studies of aggregate earnings have derived empirical support for this proposition, ${ }^{11}$ there is no consensus as to the institutional factors that might be responsible. A clearer understanding of why a recession may not put much "bite" on union wages seems desirable before standard monetary and fiscal policies are supplemented by auxiliary policies aimed at moderating wage increases.

There are several potential explanations of cyclically insensitive wage

table 1 sources) are not, however, corrected for variations in labor quality and hence do not reflect effective wage cuts that occur via demotion or other wage-drift mechanisms.

11. See, for example, Ashenfelter and others, "Trade Unions." 
changes. First, for internal political reasons developed in the previous section, unions may simply ignore market conditions in setting wage objectives, except in cases of serious threat to employment and membership. Second, current market conditions may in fact influence currently negotiated union wage changes, but deferred wage increases negotiated in previous years may dominate average changes. With the spread of multiyear labor agreements in the postwar period, wages negotiated in any given year cover less than half of the organized workers receiving increases during that year. As a result, the inertia of deferred increases may dampen the response of union wages to current policy stimuli, even though currently negotiated wages may be as cyclically sensitive as nonunion wages. ${ }^{12}$ Finally, union wage demands may be influenced by "equity" considerations as well as current market conditions. Where the equity objective takes the form of maintaining a target relative wage and where the relativewage patterns tend to be disturbed before a deflationary period, macroeconomic policy may not have much influence on even currently negotiated wages. To the extent that nonunion employers seek to maintain a differential with the union sector, the insulation of wages from market stimuli could spread throughout the economy. If this form of wage interdependence is important, a crucial empirical issue is the speed with which wages adjust to reestablish the target differential.

The empirical analysis in this section seeks to establish the weight to be accorded these alternatives and their role in recent wage behavior. Wage determination is examined separately for the union and nonunion sectors in an effort to describe more fully the differences in the underlying behavior, and to bring out interactions that are obscured in the earnings data. In evaluating the results, it should be recognized that observed earnings changes are not a simple weighted average of wage changes in the union and nonunion sectors. To clarify the relation between the analysis in this section and standard wage-adjustment models using earnings as the dependent variable, consider

$$
E=T\left(\dot{W}^{u}+\dot{D}\right)+(1-T) \dot{W}^{n},
$$

in which the rate of change of earnings, $E$, is expressed as the weighted average of wage developments for union and nonunion workers $(T$ is the percentage of organized workers). Wage changes in the organized

12. For some simulation evidence on this point, see Martin Neil Baily's article in this issue. 
sector will reflect the rate of change of negotiated wages, $\dot{W}^{u}$, plus the contribution of wage drift, $\dot{D}$. Earnings may drift from negotiated rates in the organized sector because the duration of many labor agreements inhibits immediate negotiated adjustments to unanticipated variations in the determinants of wages and also because of the centralization of bargaining structures in some sectors. ${ }^{18}$ These features of wage determination appear less important in the nonunion sector; recall from the previous section, for example, the sensitivity of the percent of nonunion workers receiving general wage increases to changing economic conditions. Hence, the wage changes of unorganized workers, $W^{n}$, are assumed to be free of a drift component. The drift component, or tendency for observed earnings increases to exceed the weighted average of union and nonunion wage changes, has been of some importance since 1967. Between 1967 and 1973, drift in manufacturing varied between 0.7 and 1.8 percent per year, computed on a base of average hourly earnings adjusted for overtime and interindustry shifts.

In principle, wage imitation can influence any component of equation 1 , and thus reduce the responsiveness of earnings changes to changes in macroeconomic policy. However, the empirical tests in this paper are restricted to spillovers influencing $\dot{W}^{u}$ and $\dot{W}^{n}$, as well as wage relationships within the unionized sector. Although the size of the drift component may reflect union "equity" objectives, this influence has generally been noted in countries with centralized collective bargaining systems in which attempts by the labor movement to achieve greater equality in the structure of negotiated rates are thwarted by the subsequent behavior of drift. ${ }^{14}$ Such redistributional efforts are not as marked or as capable of coordination in a bargaining system as decentralized as that in the United States, where there are few barriers to reestablishing a perceived distributional anomaly through official union negotiations. The role of drift in the spillover process is therefore left for another paper.

13. For a recent discussion of these issues, see Robert E. Hall, "The Process of Inflation in the Labor Market," $B P E A, 2: 1974$, pp. 343-93. See also E. H. PhelpsBrown, "Wage Drift," Economica, vol. 29 (November 1962), pp. 339-56.

14. For some examples and some evidence, see T. L. Johnston, Collective Bargaining in Sweden (London: George Allen and Unwin, 1962), chap. 16; William Fellner and others, The Problem of Rising Prices (Paris: Organisation for European Economic Co-operation, 1961), pp. 300-03; and Organisation for Economic Co-operation and Development, Norway, OECD Economic Surveys (Paris: OECD, 1975), p. 18. 
Instead, this section examines the wage relationships between organized and unorganized workers in manufacturing along with the influence from union wage settlements in nonmanufacturing and the public sector. Beginning with the union sector, consider a fairly general form of a moneywage adjustment model,

$$
\dot{W}_{t}=f\left(u_{t}\right)+\beta \dot{W}_{t}^{*},
$$

in which $f(u)$ represents disequilibrium (market) forces and $\dot{W}^{e}$ represents the rate of change of expected money wages. Clearly, in a discussion of wage contagion, the determinants of expected wages are crucial, and the literature suggests three main influences on wage expectations.

The most common hypothesis concerning wage expectations is that workers seek to maintain their real standard of living. This implies the specification $\dot{W}_{t}^{e}=g \sum_{i}\left(\dot{P}_{t-i}\right)$, where $P$ is prices, which upon substitition into equation 2 yields the familiar price-wage process specified in most empirical wage-adjustment equations.

A second assumption is that workers seek to protect their share of total income and output. Virtually every organized labor movement advocates an increase in labor's share, and functional shares are apparently of importance in motivating wage demands in some European countries with relatively centralized bargaining arrangements. ${ }^{15}$ However, from the perspective of negotiators of individual labor agreements in the decentralized bargaining system of the United States, macro distribution goals are a futile objective. On the other hand, profits in the firm or industry of the union do provide a realistic target, and thus profit variables have been included in many empirical models in an effort to detect the effects of institutional forces.

The third major expectations hypothesis, which has not received as much empirical attention as one might expect given the folklore of wage interdependence, is that union wage determination is influenced by notions of "fairness" or "equity" that are defined by reference to the wages received by other workers in the same union, by workers doing similar work in other industries, or by workers in other occupations with which a differential has been maintained by the force of custom. From this perspective, changes in the rate of inflation, in labor market conditions, or in institu-

15. For discussion and evidence on this issue, see George L. Perry, "Determinants of Wage Inflation around the World," $B P E A, 2: 1975$, pp. 403-35; and OECD. Ger many, Economic Surveys (Paris: OECD, 1975). 
tional arrangements (for example, bargaining structures and contract durations) attain much of their importance in the inflationary process through their disturbing influence on the pattern of relative wages. Not only does the hypothesis open up an array of intersectoral relationships, in which wages determined by bargaining or competitive forces in one sector may influence wages elsewhere, but it opens up mechanisms through which government redistribution policies may be transmitted to sectors that are not directly influenced. ${ }^{16}$ On the other hand, the hypothesis offers no guidance on the domain of wage interdependence. If future wage changes in sector $i$ depend in part on the current wage in $i$ relative to sector $j$, which sectors constitute $j$ ? If all sectors exert an equal influence, the naive contagion hypothesis reasserts itself, but this has been ruled out by results such as those reported in table 1 . This problem is discussed more thoroughly when individual contract data are examined below.

\section{EMPIRICAL SPECIFICATION}

Each of the hypotheses concerning wage expectations just discussed was incorporated into the empirical analysis reported below. The dependent variables were alternately the median percentage rate of change of money wages for union and for nonunion workers, as reported in the BLS surveys, Wage Developments in Manufacturing, described in the previous section. The dependent variable for the organized sector requires further comment. For union workers, the wage decisions are taken at the time of a contract renegotiation, so that the preferable dependent variable would be the annual rate of change of the value of the contract over its life. Unfortunately, data using this wage concept have not been available long enough for fruitful econometric analysis, and the same is true of data that include the value of fringe benefits. As an alternative measure of the outcome of current union negotiations, the rate of change of money wages provided for in the first year of currently negotiated contracts is adopted. This measure excludes first-year cost-of-living adjustments (COLA) and therefore captures wage responses to market and institutional influences exerted up to the negotiations. In the present analysis, this wage concept captures best the sensitivity of union wage decisions to current labor

16. Edward M. Gramlich, "Impact of Minimum Wages on Other Wages, Employment, and Family Incomes," BPEA, 2:1976, pp. 409-51. 
market conditions. To assess the drag on union wage adjustments attributable to the presence of multiyear contracts, the behavior of effective union wage changes-current wage changes plus deferred increases, plus COLA -is also analyzed and compared with the results for current changes. (A series restricted to deferred wage increases is not available.)

To get a period sufficiently long to permit useful analysis, one must rely on annual data. In the regression analysis, the wage changes are related to variables representing labor market pressure, price changes, profits, the incomes policy of the early seventies, and relative-wage comparisons, each of which is discussed in the subsequent paragraphs.

Turning first to the role of labor market pressure in wage determination in the organized sector, both the lag structure and the cyclical sensitivity of wage changes may differ from those in the nonunion sector. The lag structure of labor market influence may be affected by the duration of labor agreements. Labor market pressure may be a weak determinant of union bargaining demands for two reasons. First, in their bargaining behavior, unions are more interested in the employment of their current membership than in the potential size of their membership. Second, in an environment in which bargaining objectives are politically determined, and institutional rules indicate clearly which minority is at risk, the majority may rationally decide to ignore market pressures in their wage demands. In trial regressions the "Perry-weighted" series on the unemployment rate was tested in linear and nonlinear form as was an employment-change variable constructed by summing the rate of change of production-worker employment in each two-digit manufacturing sector weighted by the percent of union (or nonunion) workers in that sector. Statistically, it was not possible to choose between models with general and sector-specific labor market pressure in the analysis of union wage changes. The nonlinear unemployment and the weighted employment-change specifications were strongest in the union sector while the linear unemployment specification was superior in the nonunion sector. The unemployment specifications are reported for both sectors to facilitate comparisons. Despite considerable experimentation with lagged values of the variables reflecting labor market pressure in both the union and nonunion regressions, only the current values were significant.

Price changes are assumed to influence workers in all sectors equally, and the preceding December-to-December change of the consumer price index is used for this purpose. Experiments with alternative lag structures confirmed that the duration of employment contracts affects the time path 
of price influence on wages. First-year wage adjustments in currently negotiated union agreements are significantly influenced by price changes that occurred up to two years earlier, as would be expected when actual price changes differ from expected changes in a sector dominated by two- and three-year labor agreements. On the other hand, only one-year lags on price changes are significant in the nonunion sector (where wage revisions are generally considered annually). In the regressions on effective union wage change, lags of longer than one year are also insignificant. Deferred contractual wage increases appear to be based in part on price expectations at the time of negotiations that run counter to later price experience sufficiently to cancel the lagged influence on first-year negotiated wages.

The profit rate, as many have observed, is not an independent variable mandated by any derivation of disequilibrium wage adjustments in competitive markets. Instead, it has been offered as a determinant of union wage objectives in wage models that acknowledge some role for collective bargaining. But this convention has yielded puzzling results. The closer past studies have come to isolating wage adjustments for unionized workers, the weaker has been the role of profits. ${ }^{17}$ Nevertheless, the influence of profits on union wage changes was investigated in several unreported regressions. A profit rate for the unionized sector of manufacturing was developed by summing Federal Trade Commission data on after-tax profits as a percent of stockholders' equity in two-digit manufacturing sectors weighted by the percent of union workers in each sector. The results were fully consistent with the findings of other studies of the unionized sector. Neither current nor lagged values of the level or change in profits were significantly related to negotiated wage changes in manufacturing. As a result, profits have not been included in the results reported below. ${ }^{18}$

17. Indeed, there is some indication that profits variables have, if anything, been more significant in the determination of nonunion wages. See the discussion in George E. Johnson, "Economic Analysis of Trade Unionism," American Economic Review, vol. 65 (May 1975), pp. 23-28, and studies cited therein. An earlier study of the contractual union wage changes analyzed below found no significant relationship between contractual wages and the profit rate. See Daniel S. Hamermesh, "Wage Bargains, Threshold Effects, and the Phillips Curve," Quarterly Journal of Economics, vol. 84 (August 1970), pp. 501-17.

18. This result, along with the relatively short lag structures on other independent variables, parallels the findings of a recent study of average hourly earnings spillovers between groupings of two-digit manufacturing industries. See Y. P. Mehra, "Spillovers in Wage Determination in U.S. Manufacturing Industries," Review of Economics and Statistics, vol. 58 (August 1976), pp. 300-12. 
In mid-August 1971, the Nixon administration initiated an incomes policy which ultimately consisted of four phases. The first, a 90-day freeze, occurred after most of the major 1971 wage negotiations were completed. Phase II, which established a 5.5 percent wage guideline, was in effect throughout 1972. Subsequent phases were more flexible. Given the paucity of observations available in the annual data, the policy period is represented (relatively crudely) by a dummy variable (PHASE) taking the value of unity in 1972 and 1973 and zero otherwise.

The final set of variables is included as a test for union-nonunion, and union-union wage spillovers. The maintained hypothesis is that union groups have a target relative-wage differential, $R W^{*}$, with reference to nonunion workers and to other union groups that they seek to maintain through collective bargaining. If $R W^{*}$ represents the target union relative wage and $U^{-1}$ is the reciprocal of the unemployment rate, then

$$
\dot{W}_{t}^{u}=\beta_{0}+\beta_{1} U_{t}^{-1}+\beta_{2} \dot{P}_{t-1}+\gamma\left(R W_{t}^{*}-R W_{t-1}\right)+\epsilon .
$$

In this equation, $\gamma$ is positive and measures the fraction of the relativewage disequilibrium removed during negotiations (when the dependent variable is current union wage changes). In the empirical work reported below, the target relative wage is impounded in the constant term and the following regression is estimated:

$$
\dot{W}_{t}^{u}=\left(\beta_{0}+\gamma R W_{t}^{*}\right)+\beta_{1} U_{t}^{-1}+\beta_{2} \dot{P}_{t-1}-\gamma R W_{t-1}+\epsilon .
$$

This specification assumes no change in the target differential over the estimating period. To the extent that union militancy is indexed by changes in union membership, as some previous studies have argued, this assumption is consistent with the facts in the private sector.

Nonunion employers may also wish to keep wages within a certain disstance of the union scale, in order to reduce the probability of union organization. As noted earlier, however, this effect may have been much weaker during the postwar period when further unionization in the private sector has not been extensive.

In the regression analysis presented below, the proportionate differentials between wages in unionized manufacturing and various reference sectors are used as variables for detecting spillover effects. The proportionate difference is calculated as $100\left(\log W^{u}-\log W^{i}\right)$, where $W^{u}$ is the union wage in manufacturing and $W^{i}$ is the wage in the reference sector. In the regressions for union wage changes, a negative coefficient is expected on all spillover variables, while the expected sign is positive in 
the regressions for nonunion wage changes. The union-nonunion differential, $N U$ ( $R W$ in equation 3 ) is constructed from the data for manufacturing from Current Wage Developments referred to above. There are several alternative reference sectors for union-union wage spillovers, some of which have exhibited dramatic changes. Foremost among these is the relative increase of nonmanufacturing negotiated wages, which has been spearheaded by, but not restricted to, changes in construction wages. Data on negotiated rates in all nonmanufacturing are from Current Wage Developments and are used to construct the differential, $N M$, with union rates in manufacturing. The Bureau of Labor Statistics series on union wage rates in the building trades is also introduced as a separate reference wage and used to construct the differential, CON. Finally, the late sixties and early seventies saw a striking growth in unionization, collective bargaining, and the relative wage in the public sector. Yet there are surprisingly few time series on wages in the public sector. One of the few covers salaries of police and firemen in major metropolitan areas. The differential of this measure relative to union wage rates in manufacturing is PUB.

\section{SPILLOVER RESULTS}

The regression model in equation 3 was used to analyze annual changes in current union, effective union, and nonunion wages for the period 1960-75. A comparison of the results reported in table 2 for the alternate dependent variables reveals much about the sources of the relative cyclical insensitivity of union wages.

First, a comparison of the regressions for effective wage changes with nonunion changes confirms that nonunion firms are more responsive to labor market pressure (compare regressions 6 and 11). ${ }^{19}$ However, most of the difference in the average wage responsiveness of the union and nonunion sectors of manufacturing appears attributable to the prevalence of multiyear contracts in unionized manufacturing, where only 1 percent of labor agreements covering at least 1,000 workers have a duration of one

19. This result coincides with the findings of economists who have attempted to develop inferences about the wages of union and nonunion workers from the analysis of average hourly earnings data. See Ashenfelter and others, "Trade Unions," and George E. Johnson, "The Determination of Wages in the Union and Nonunion Sectors" (University of Michigan, May 1975; processed). 


\begin{tabular}{|c|c|c|c|c|c|}
\hline \multirow{3}{*}{$\begin{array}{l}\text { Type of wage } \\
\text { and regression }\end{array}$} & \multirow[b]{3}{*}{ Constant } & & & \multicolumn{2}{|r|}{ Variable } \\
\hline & & \multicolumn{2}{|c|}{ Unemployment rateb } & \multicolumn{2}{|c|}{ Price change $^{\circ}$} \\
\hline & & $U_{\mathrm{p}}$ & $U_{p}^{-1}$ & $\dot{P}_{-1}$ & $\dot{P}_{-2}$ \\
\hline \multicolumn{6}{|l|}{ Current union } \\
\hline 1 & $\begin{array}{c}5.550 \\
(7.88)\end{array}$ & $\begin{array}{c}-0.836 \\
(4.74)\end{array}$ & $\ldots$ & $\begin{array}{l}0.334 \\
(2.87)\end{array}$ & $\begin{array}{l}0.573 \\
(3.28)\end{array}$ \\
\hline 2 & $\begin{array}{c}-0.752 \\
(0.87)\end{array}$ & $\ldots$ & $\begin{array}{c}0.114 \\
(4.12)\end{array}$ & $\begin{array}{l}0.345 \\
(2.72)\end{array}$ & $\begin{array}{r}0.517 \\
(2.74)\end{array}$ \\
\hline 3 & $\begin{array}{l}0.764 \\
(0.74)\end{array}$ & $\ldots$ & $\begin{array}{r}0.091 \\
(3.24)\end{array}$ & $\begin{array}{l}-0.052 \\
(-0.23)\end{array}$ & $\begin{array}{l}0.523 \\
(3.15)\end{array}$ \\
\hline 4 & $\begin{array}{l}1.277 \\
(2.15)\end{array}$ & $\ldots$ & $\begin{array}{l}0.078 \\
(4.87)\end{array}$ & $\begin{array}{c}0.018 \\
(0.20)\end{array}$ & $\begin{array}{r}0.291 \\
(2.82)\end{array}$ \\
\hline 5 & $\begin{array}{l}1.592 \\
(2.27)\end{array}$ & $\ldots$ & $\begin{array}{r}0.061 \\
(3.10)\end{array}$ & $\begin{array}{l}0.008 \\
(0.08)\end{array}$ & $\begin{array}{l}0.354 \\
(3.19)\end{array}$ \\
\hline \multicolumn{6}{|l|}{ Effective unton } \\
\hline 6 & $\begin{array}{c}3.184 \\
(5.46)\end{array}$ & $\begin{array}{c}-0.248 \\
(1.75)\end{array}$ & $\cdots$ & $\begin{array}{r}0.587 \\
(11.98)\end{array}$ & $\cdots$ \\
\hline 7 & $\begin{array}{l}1.334 \\
(2.08)\end{array}$ & ... & $\begin{array}{l}0.033 \\
(1.55)\end{array}$ & $\begin{array}{c}0.580 \\
(11.73)\end{array}$ & $\ldots$ \\
\hline 8 & $\begin{array}{l}3.075 \\
(6.14)\end{array}$ & $\ldots$ & $\begin{array}{l}0.006 \\
(0.44)\end{array}$ & $\begin{array}{c}0.133 \\
(1.34)\end{array}$ & $\ldots$ \\
\hline 9 & $\begin{array}{l}7.604 \\
(4.96)\end{array}$ & $\ldots$ & $\begin{array}{r}0.015 \\
(1.02)\end{array}$ & $\begin{array}{l}0.287 \\
(3.41)\end{array}$ & $\ldots$ \\
\hline 10 & $\begin{array}{l}2.814 \\
(4.25)\end{array}$ & $\ldots$ & $\begin{array}{l}0.005 \\
(0.28)\end{array}$ & $\begin{array}{r}0.322 \\
(3.25)\end{array}$ & $\cdots$ \\
\hline \multicolumn{6}{|l|}{ Nonunion } \\
\hline 11 & $\begin{array}{c}5.254 \\
(8.90)\end{array}$ & $\begin{array}{c}-0.820 \\
(5.71)\end{array}$ & $\ldots$ & $\begin{array}{r}0.547 \\
(11.03)\end{array}$ & ... \\
\hline 12 & $\begin{array}{c}5.691 \\
(6.165)\end{array}$ & $\begin{array}{c}-0.843 \\
(5.55)\end{array}$ & $\cdots$ & $\begin{array}{r}0.557 \\
(10.37)\end{array}$ & $\cdots$ \\
\hline
\end{tabular}

Sources: Derived from text equation 3 using wage data from the following sources. Union and nonunion, 1959-64, William Davis and Lily Mary David, "Pattern of Wages and Benefit Changes in Manufacturing," Monthly Labor Review, vol. 91 (February 1968), p. 43, and 1965-75, Diane C. Bayless, "Wage Gains for Manufacturing Workers Show Different Trends for Union and Nonunion Sectors in 1975," Current Wage Developments, vol. 28 (July 1976), tables 2, 4, pp. 62, 63; building trades, U.S. Bureau of Labor Statistics, Handbook of Labor Statistics, 1974, p. 219, and Mark Sieling, "Union Wage Rates in Building Trades," Monthly Labor Review, vol. 99 (July 1976), p. 39; public employees, Joan D. Borum, "Starting Pay of Metropolitan Police, Firefighters Rose 6.5 Percent in 1974," Current Wage Developments, vol. 27 (December 1975), table 4, p. 46; nonmanufacturing, Current Wage Developments, vol. 28 (April 1976), p. 46.

a. The regressions use annual data. The numbers in parentheses are $t$-statistics, The dependent variable is the median percentage rate of wage change in the respective sectors; see text for a detailed description.

b. The Perry weighted unemployment rate is used; see George L. Perry, "Changing Labor Markets and Inflation," BPEA, 3:1970, pp. 411-41. 
Manufacturing, $1960-7^{\circ}$

Summary statistic

\begin{tabular}{|c|c|c|c|c|c|c|c|}
\hline \multirow[b]{2}{*}{$N U_{-1}^{d}$} & \multicolumn{3}{|c|}{ Wage differential } & \multirow{2}{*}{$\begin{array}{c}\text { Incomes- } \\
\text { policy } \\
- \text { dummy } \\
\text { PHASE }\end{array}$} & \multirow[b]{2}{*}{$R^{2}$} & \multirow{2}{*}{$\begin{array}{c}\text { Standard } \\
\text { error of } \\
\text { estimate }\end{array}$} & \multirow{2}{*}{$\begin{array}{l}\text { Durbin- } \\
\text { Watson }\end{array}$} \\
\hline & $N M_{-1}{ }^{\circ}$ & $C O N_{-1}^{i}$ & $P U B_{-1}{ }^{g}$ & & & & \\
\hline$\cdots$ & $\ldots$ & $\cdots$ & $\ldots$ & $\begin{array}{c}-0.426 \\
(0.69)\end{array}$ & 0.91 & 0.950 & 1.66 \\
\hline$\cdots$ & $\cdots$ & $\cdots$ & $\ldots$ & $\begin{array}{c}-0.108 \\
(0.16)\end{array}$ & 0.89 & 0.761 & 1.72 \\
\hline $\begin{array}{c}-0.389 \\
(2.28)\end{array}$ & $\begin{array}{c}-0.314 \\
(2.15)\end{array}$ & $\ldots$ & ... & $\begin{array}{r}-2.497 \\
(1.91)\end{array}$ & 0.92 & 0.666 & 1.60 \\
\hline $\begin{array}{c}-0.496 \\
(5.82)\end{array}$ & .. & $\begin{array}{c}-0.232 \\
(5.63)\end{array}$ & $\ldots$ & $\begin{array}{c}-2.901 \\
(4.67)\end{array}$ & 0.97 & 0.385 & 2.08 \\
\hline $\begin{array}{c}-0.192 \\
(4.80)\end{array}$ & $\ldots$ & $\ldots$ & $\begin{array}{r}-0.193 \\
(4.88)\end{array}$ & $\begin{array}{c}-1.943 \\
(3.51)\end{array}$ & 0.97 & 0.429 & 1.80 \\
\hline$\cdots$ & $\cdots$ & $\cdots$ & $\cdots$ & $\begin{array}{r}1.474 \\
(3.37)\end{array}$ & 0.91 & 0.577 & 2.16 \\
\hline$\cdots$ & $\cdots$ & $\cdots$ & $\cdots$ & $\begin{array}{r}1.539 \\
(3.44)\end{array}$ & 0.90 & 0.591 & 2.25 \\
\hline $\begin{array}{c}-0.443 \\
(5.19)\end{array}$ & $\begin{array}{c}-0.356 \\
(4.90)\end{array}$ & $\cdots$ & $\ldots$ & $\begin{array}{c}-1.160 \\
(1.86)\end{array}$ & 0.97 & 0.332 & 1.87 \\
\hline $\begin{array}{c}-0.336 \\
(4.34)\end{array}$ & ... & $\begin{array}{c}-0.152 \\
(4.03)\end{array}$ & $\cdots$ & $\begin{array}{c}-0.513 \\
(0.86)\end{array}$ & 0.96 & 0.378 & 1.83 \\
\hline $\begin{array}{c}-0.132 \\
(3.33)\end{array}$ & $\ldots$ & $\cdots$ & $\begin{array}{c}-0.119 \\
(3.03)\end{array}$ & $\begin{array}{c}0.273 \\
(0.48)\end{array}$ & 0.94 & 0.442 & 1.88 \\
\hline$\cdots$ & $\cdots$ & $\cdots$ & $\cdots$ & $\begin{array}{l}1.340 \\
(3.03)\end{array}$ & 0.92 & 0.584 & 2.66 \\
\hline $\begin{array}{c}-0.019 \\
(0.63)\end{array}$ & $\ldots$ & $\ldots$ & $\cdots$ & $\begin{array}{r}1.390 \\
(3.02)\end{array}$ & 0.89 & 0.599 & 2.69 \\
\hline
\end{tabular}

c. Change in consumer price index, December to December, defined as $\left(P_{t}-P_{t-1}\right) / P_{t-1}$, where $P_{t}$ is the index in a given December and $P_{t-1}$ is the index for the previous December.

d. Proportionate difference between the union and nonunion wage rates in manufacturing. $N U=100$ $\left(\log W^{*}-\log W^{n}\right)$, where $W^{v}=$ union wages and $W^{n}=$ nonunion wages.

e. Proportionate difference between wage rates in unionized manufacturing and unionized nonmanufacturing (defined as above).

f. Proportionate difference between union wage rates in manufacturing and indexed wage rates in the building trades (defined as above).

g. Proportionate difference between union wage rates in manufacturing and the wages of public employees as indexed by the maximum salary scales of police and firemen (defined as above).

$h$. The value of the dummy variable is unity in 1972 and 1973 (the years of the incomes policy of the Nixon administration) and zero in other years. 
year or less. This conclusion follows from comparing the effect of labor market pressure on current and effective union wage changes (for example, regressions 1 and 6). The relationship between current union wage changes and labor market pressures, as indexed by the Perry weighted unemployment variable, is both economically and statistically significant, and the point estimate on the unemployment term is essentially the same as that obtained in the nonunion equation (regression 11). In the more comprehensive measure of effective union wages, which includes deferred increases, the point estimate of the response of union wages to unemployment is substantially lower and not quite statistically significant. Attempts to rehabilitate the influence of labor market pressures on effective union wage changes by the introduction of lagged values of unemployment did not change the results significantly. The burden of the evidence is that the impact of labor market disequilibrium is limited to firstyear wage changes in union agreements, but this impact approaches that observed in the nonunion sector of the industry. Indeed, the results imply that there is little difference between the two sectors in the response of current wage decisions to macroeconomic policy impacts on unemployment. Instead, union wage inflexibility is mainly a by-product of the duration of labor agreements.

This story is complicated to the extent that there are important wage interdependencies between sectors. If "customary" wage differentials are disturbed during business expansions, but the opportunities to restore them occur some years later when the labor agreements expire, the sensitivity of even current wage changes to unemployment may be offset by efforts to regain lost relative-wage positions. Regressions 3, 4, and 5 explore the relative-wage influence on first-year wage changes in current union settlements. Since the variables are defined as the (lagged) proportionate difference between the union wage in manufacturing on the one hand and, on the other, the wage in nonunion manufacturing, $N U$, unionized nonmanufacturing, $N M$, the building trades, $C O N$, and the public sector, $P U B$, each taken separately, a negative coefficient is expected if wage interdependence exists.

Each set of spillover variables tested is statistically significant with the expected sign, and the statistical qualities of the regressions that include the relative-wage variables are superior, as judged by the improvement in the Durbin-Watson statistic and the fall in the standard error of the regression. The regressions confirm the existence of separate channels of 
influence through which the nonunion sector and other union contracts operate simultaneously on union settlements in manufacturing. Wage increases in the first year of currently negotiated contracts restore about 40 to 50 percent of the prior year's discrepancy between the actual and target union-nonunion wage differential. The response to interunion relativewage disequilibria is less pronounced, although still statistically significant. First-year union wage changes in manufacturing make up just about 16 percent of the relative-wage disequilibrium between union workers in manufacturing and nonmanufacturing, and the coefficients on the buildingtrade and public-sector differentials indicate similar rates of response. ${ }^{20}$ A similar pattern of relative-wage coefficients emerges in the equations on effective wage change (regressions 8,9 , and 10). Union wages adjust most rapidly to movements in the union-nonunion differential, although the inclusion of deferred increases in the measure of effective wage change reduces the size of the coefficient. ${ }^{21}$

The major disturbances in the relative-wage relationships between unions occurred during periods of inflation, with the result that the addition of the relative-wage variables to the regression is associated with a fall in the magnitude of the price-change variable. These results suggest that money-wage inflation in the unionized sector may have reflected less an increasing sensitivity to inflation than a response to increasing disequilibrium in interunion and union-nonunion wage differentials. Once the spillover variables are included in the effective-wage regression, for example, the coefficients on the inflation variable drop to about the magnitude that was reported in earnings-adjustment equations estimated for periods prior to the acceleration of inflation in the late 1960s. Indeed, a literal reading of the regressions on effective wage change suggests that the

20. The various interunion differentials are sufficiently intercorrelated in the annual data that it is not possible to untangle their separate influences on the dependent variable when they are included in the regression simultaneously.

21. If $R W$ is lagged, $W_{t-1}^{u}$ appears on both sides of the regression equation, placing a restriction on the coefficient $\gamma$ (equation 3 ) and raising the question of whether wages in the reference sectors play the role attributed to them in the text. As an alternative specification, the regressions in table 2 were rerun with each component of $R W$ entered separately. Unfortunately, these regressions suffered from multicollinearity (largely between union reference wage rates and lagged price changes). Nevertheless, in the union regressions, $W_{t-1}^{\prime \prime}$ enters negatively as expected (but with coefficients ranging from -0.4 to -0.7 depending on the specification), and the coefficient on the nonunion reference wage is significant and positive, and ranges from 0.8 to 1.0 . 
responsiveness of negotiated wages to price inflation would have been cut roughly in half if the wage relationships had remained stable throughout the period.

How important have relative-wage disequilibria been in the actual movements of union wages in recent years? In figure 1, the relative-wage series used in the regression analysis is graphed for the period 1959-75. Of the differentials examined, the union wage in manufacturing exceeds only the nonunion manufacturing wage. The earlier regression analysis indicates that nonunion wage changes are highly responsive to market conditions and hence likely to alter the equilibrium differential, but unionwage adjustments are highly sensitive to this differential. In fact, the union-nonunion relative-wage series has less variation than the interunion differentials. From a plateau reached early in the sixties, the union relative wage in manufacturing fell during the tight labor markets of the late sixties, and created an upward pressure on union wages. During the 196770 period, the level of $N U$ relative to, say, 1965 would at most have added 0.8 percentage point a year to first-year union wage changes and 0.65 percentage point to effective union wage increases, based on the regression results in table 2 . Since 1969 , however, $N U$ has risen to its highest level of the period, moderating union wage changes in recent years. ${ }^{22}$ The regression results in table 2 imply that first-year increases in current negotiations would have been as much as 1.3 percentage points higher in 1975 and 2.2 percentage points higher in 1976 if the union-nonunion differential had been at its 1969 level.

The most dramatic feature of figure 1 is the extent of the alteration of gross interunion wage differentials since 1959 . Union wages in manufacturing have fallen relative to union scales in other major sectors; the change is particularly acute relative to the building trades and the public sector. ${ }^{23}$ Particularly during the late sixties and early seventies, this differ-

22. The wage differentials in figure 1 are unadjusted for sectoral differences in labor quality and the like. For evidence that net union-nonunion wage differentials have followed a similar path since 1967, see Orley Ashenfelter, "Union Relative Wage Effects: New Evidence and a Survey of Their Implications for Wage Inflation," Working Paper 89 (Princeton University, Industrial Relations Section, August 1976; processed).

23. The remarkable increase in relative wages in unionized construction has been followed by a rapid expansion of nonunion construction activity. See Herbert $\mathbf{R}$. Northrup and Howard G. Foster, Open Shop Construction (University of Pennsylvania Press, 1975). The growth of the nonunion sector has stimulated interest among the national construction unions in acquiring greater influence over local bargaining arrangements in the industry. 
Figure 1. Wage Rates in Manufacturing Unions Relative to Wages in Other Sectors, 1959-75

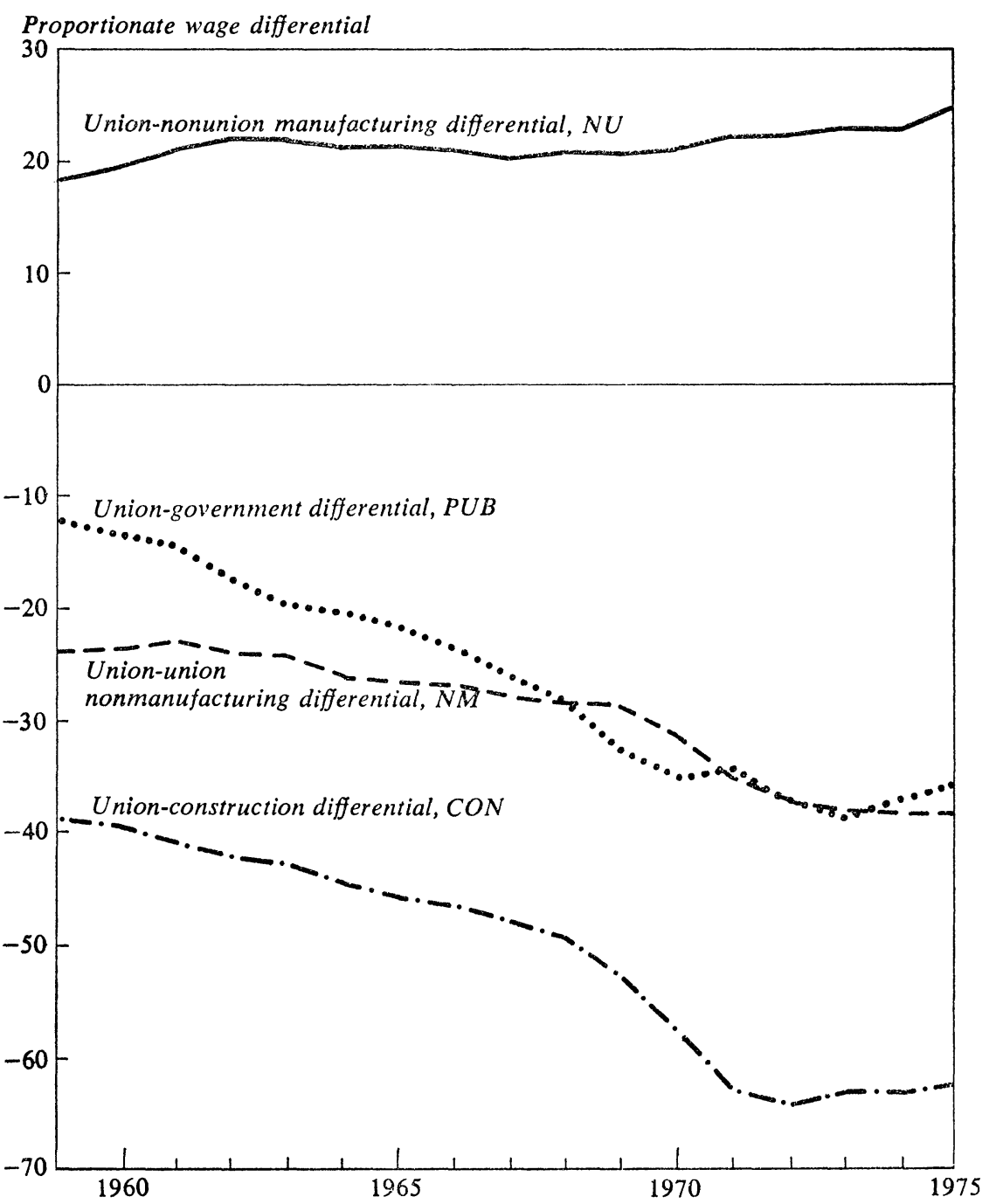

Sources: See table 2.

a. $100\left(\log W^{i}-\log W^{j}\right)$, where $W^{i}=$ union wages and $W^{j}=$ wages in the respective comparison sector. 
ential added an upward pressure on union wages in manufacturing, despite the weaker influence of the interunion differentials. In the recession year of 1971, for example, the regression results imply that current union wage changes in manufacturing were around 2 percentage points higher than they would have been if the interunion differentials existing in 1969 had been maintained. During the recession in the early seventies, union wage interdependencies among major industrial sectors tended to counteract the effects of growing unemployment on negotiated wages in manufacturing, thereby adding significant wage inflexibility in the face of a weakening labor market. Only since 1972 and 1973 has the widening in major interunion differentials been halted or reversed, reducing spillover pressures among major sectors in the current recession.

What influence have these developments had on wages in the nonunion sector? Early in the paper it was noted that any tendency to dismiss the role of unions in the aggregate wage-determination process on the basis of their extent of organization of the labor force implies that "threat" effects, or wage spillovers from the union to the nonunion sector, are of minor importance. Money-wage increases in nonunion manufacturing for 1960-75 are analyzed in the regressions in the bottom panel of table 2. Given the definition of the union-nonunion wage differential in manufacturing, a significant positive coefficient would signify an operative threat effect. However, the spillover variable specified in the nonunion regressions does not approach normal standards of statistical significance. Over the period covered by the analysis, union wages in manufacturing do not appear to have influenced wage increases in nonunion manufacturing. (When the components of $N U$ are entered separately in the nonunion regression, the union reference wage is negative and not statistically significant, confirming the absence of significant spillovers from the nonunion sector.) The absence of a discernible threat effect is perhaps unsurprising during a period in which private-sector organizing has not been very extensive or successful. And if there is no spillover from union to nonunion wages, as this result suggests, there is some question of the efficacy of wage-restraint programs that assume that the union sector is the leader in the general money-wage dynamics of the economy. Whatever the role of wage contagion among union jurisdictions, the infection apparently has not reached nonunion workers by a direct route in recent years. ${ }^{24}$

24. For a parallel finding, see Johnson, "Determination of Wages." 
Figure 2. Annual Rate of Change of Union and Nonunion Wage Rates in Manufacturing, 1959-75

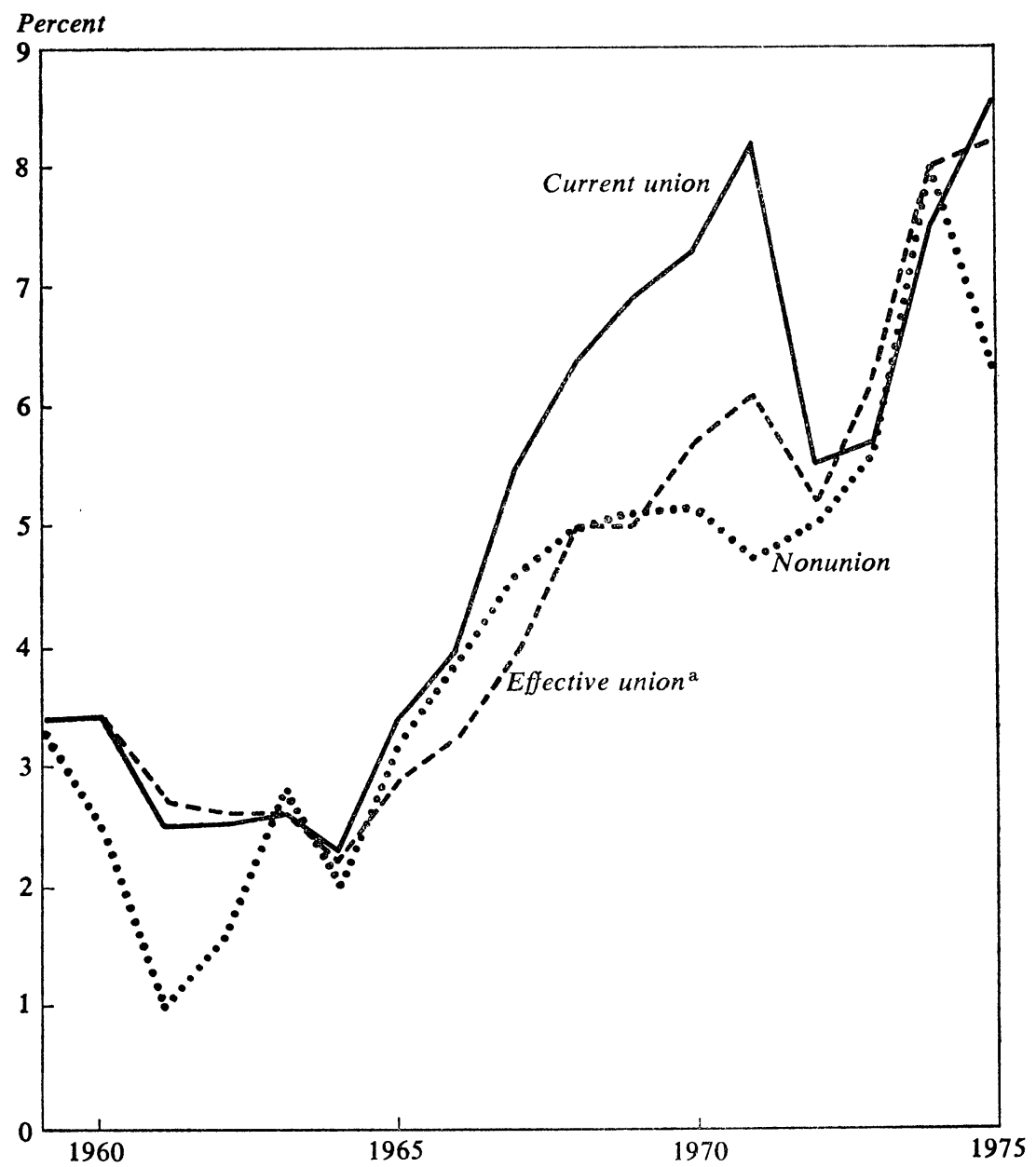

Sources: See table 2.

a. Current wage changes, plus deferred wage increases, plus cost-of-living increases.

THE INCOMES POLICY OF THE EARLY SEVENTIES

Incomes policy is frequently proposed as an auxiliary to macroeconomic policies that have to confront wage and price inflexibilities. The movement of union and nonunion wages during the period of incomes policy in the 
early seventies is therefore of interest. Figure 2 graphs the annual rate of change of union and nonunion wages over the years 1959-75. The long rise from 1964 of both of the union wage concepts broke dramatically in 1972 and 1973 while the policy was operative, only to be reestablished after the policy was lifted. However, nonunion wage increases, which tapered off prior to the imposition of the policy, did not drop in parallel and in fact rose in 1973.

The regressions in table 2 incorporate a dummy variable (PHASE) to test for the effect of the incomes policy of the Nixon administration in 1972 and 1973. While this represents a rather crude test of the policy's impact on the wage-adjustment process, limitations in the data preclude some alternatives. Nevertheless, two interesting findings emerge from a review of the PHASE coefficients. First, the policy appears to have restrained negotiated wages, but this effect is clear only in those equations that explicitly account for the influence of relative-wage disequilibria on union wages (equations 3,4 , and 5 in table 2 ).$^{25}$ One interpretation of this is that Phases II and III apparently had some success in suppressing union wage expectations generated by the disturbed relative-wage differentials of the late sixties. Second, the PHASE coefficients indicate that nonunion wage changes were significantly higher during the policy period. The PHASE coefficients in the union regressions are sensitive to the particular reference-wage comparisons used and in some of the regressions look large relative to inferences that others have drawn from studies of earnings behavior. These observations raise the possibility that important structural changes occurred in wage determination during the period. To explore this issue further, wage-change relationships for the union and nonunion sectors were reestimated for the period 1960-71 and used to predict wage changes in 1972 and 1973. For the union wage concepts, regressions including spillovers from nonunion manufacturing and unionized nonmanufacturing are used for the predictions. No relative-wage influence is included in the nonunion regression. The predicted wage movements are compared with actual changes in table 3 .

For unionized manufacturing, wage increases were significantly below predicted values, and for 1972 the dominant effect appears to have been the restraint of first-year increases. Nevertheless, there is a striking differ-

25. In these equations, the first price-change term is insignificant. Since prices as well as wages were controlled, the $P H A S E$ dummy is more likely to be significant in equations without explicit price terms as explanatory variables. 
Table 3. Actual and Predicted Wage Changes in Union and Nonunion Manufacturing, 1972 and 1973

Annual rate of change in percent; difference in percentage points

\begin{tabular}{|c|c|c|c|c|c|c|c|c|c|}
\hline \multirow[b]{2}{*}{ Year } & \multicolumn{3}{|c|}{ Current union } & \multicolumn{3}{|c|}{ Effective union } & \multicolumn{3}{|c|}{ Nonunion } \\
\hline & Actual & $\begin{array}{c}\text { Pre- } \\
\text { dicted }\end{array}$ & $\begin{array}{c}\text { Actual } \\
\text { minus } \\
\text { predicted }\end{array}$ & Actual & $\begin{array}{c}\text { Pre- } \\
\text { dicted }\end{array}$ & $\begin{array}{c}\text { Actual } \\
\text { minus } \\
\text { predicted }\end{array}$ & Actual & $\begin{array}{c}\text { Pre- } \\
\text { dicted }\end{array}$ & $\begin{array}{c}\text { Actual } \\
\text { minus } \\
\text { predicted }\end{array}$ \\
\hline 1972 & 5.5 & 7.2 & -1.7 & 5.2 & 6.4 & -1.2 & 5.0 & 3.6 & 1.4 \\
\hline 1973 & 5.7 & 6.5 & -0.8 & 6.2 & 7.1 & -0.9 & 5.6 & 4.1 & 1.5 \\
\hline
\end{tabular}

Sources: Actual, from figure 2 ; predicted, regressions 3, 8, and 11, respectively, in table 2, reestimated for the period 1960-71 without PHASE.

ence between the policy impact on current union wage changes in table 3 and the estimate of -2.5 percentage points obtained from data for 196075 (regression 3 in table 2), a finding that suggests important structural changes in the determination of first-year wage increases in current settlements. This issue is pursued in the following section.

As in table 2, the nonunion sector provides a sharp contrast with the results reported for unionized manufacturing. Nonunion wage changes are about $1 \frac{1}{2}$ percentage points above the changes predicted on the basis of a regression on data for 1960-71 - an estimate that coincides closely with the PHASE coefficient in table 2 (regression 11). The observed wage changes are quite similar in each sector and are generally in the ball park of the 5.5 percent guideline of the control period. Yet the greater responsiveness of nonunion wage changes to labor market conditions resulted in predicted wage increases during the recession of the early seventies that were well below the guideline. The fact that wage increases for both union and nonunion workers were so close to the 5.5 percent standard suggests that a guideline form of incomes policy applied during a recession may cut in both directions. While it may temporarily restrain (union) wages that otherwise would have been higher, it may also provide a target for workers whose wages would have been lower given their sensitivity to market conditions. ${ }^{28}$

More generally, the empirical results of this section raise several questions concerning the efficacy of a guideline form of incomes policy. The

26. One study of wage movements in the United Kingdom concluded that the use of a guideline during periods of high unemployment may have resulted in abnormally high union wage changes. R. G. Lipsey and J. M. Parkin, "Incomes Policy: A Reappraisal," Economica, vol. 37 (May 1970), pp. 115-38. 
case for such a policy often starts with presumed wage inflexibility in the unionized sector. While this assumption is confirmed in the analysis of effective union wage changes (which, as the broadest measure of annual union wage changes, may be the concept of primary concern to policy officials), the inflexibility appears to result from the long duration of labor agreements rather than from the insulation of current union wage settlements from market influences. In the nonunion sector, one finds the greatest degree of wage flexibility and presumably the greatest chance that a guideline policy might induce distortions. Moreover, nonunion wage flexibility is not tempered by spillovers from the union sector; within manufacturing the significant wage interdependencies flow from nonunion wages to union wages. Finally, the results reported in table 3 raise the possibility that during a recession a guideline approach may have perverse impacts on sectors with relatively flexible wages. As noted above, the effects of unemployment and prices on wages in the union sector can be dampened by the effects of relative-wage disequilibria, and this may itself be advanced as a justification for incomes policy. The effects of disequilibria appear to be real, but it is unclear whether the guideline approach eliminates them or merely postpones them for another day. ${ }^{27}$

\section{PREDICTIONS FOR 1974 AND 1975}

In this section the behavior of union and nonunion wages in the current recession is compared with the wage increases predicted by alternative wage-adjustment models. This is done by reestimating various models of wage determination for 1960-73, and using them to predict wages changes in 1974-75. The regression results are reported in table 4. Predicted values, and the differences between actual and predicted values, for 1974 and 1975 are reported in table 5. One purpose is to assess how well the models explain wage adjustments in the deepest of postwar recessions. A second purpose is to examine further how the wage-adjustment process in the union and nonunion sectors has changed during the seventies, focusing particularly on the changing role of prices and relative-wage disequilibria.

The predictions from three models are developed separately for the union and nonunion sectors. The simple structural model includes the

27. For some examples of "postponement" in European countries during the sixties, see Lloyd Ulman and Robert J. Flanagan, Wage Restraint: $A$ Study of Incomes Policies in Western Europe (University of California Press, 1971). 
reciprocal of weighted unemployment and lagged price influences and corresponds to the models underlying regressions 2,7 , and 11 in table 2 . The wage interdependence model used in predictions of union wages in manufacturing adopts the regression models with wage spillovers from both nonunion firms and nonmanufacturing unions, and corresponds with regressions 3 and 8 in table 2 . In view of the absence of a significant wage spillover from union to nonunion firms in the table 2 regressions, no predictions incorporating lagged relative-wage influences are generated for the nonunion sector. The third alternative is an autoregressive model in which nonunion employers are assumed to adjust wages to maintain their relative-wage position with other nonunion employers while union wages are alternately presumed to follow recent wage changes in the union and nonunion sector. ${ }^{28}$

A comparison of the nonunion results in tables 2 and 4 makes clear that very little change has occurred in the wage-adjustment process in nonunion manufacturing during the seventies; and in table 5 the simple structural model provides predictions of nonunion wage changes in 1974 and 1975 that are superior to those of the autoregressive model.

The story is more complicated in the union sector. The results in table 5 indicate that first-year increases in union wages have been smaller than the changes predicted by either the wage interdependence or simple structural models. The strikingly large wage changes predicted for 1975 are traceable to the 12.2 percent increase from December 1973 to December 1974 in the consumer price index. However, the structure of the union regressions has changed during the 1970s. A review of comparable regressions estimated for 1960-73 (equations 3 and 6 in table 4) and 1960-75 (equations 3 and 8 in table 2 ) indicates that first-year negotiated increases were less responsive to CPI changes during 1974-75, and more responsive to relative-wage disequilibria, than the earlier structural equations predicted. The spread of cost-of-living provisions in collective bargaining agreements may have reduced the influence of changes in the CPI on first-year negotiated increases, which exclude cost-of-living increases.

One outcome of the change in the structure of the union equations between table 4 and table 2 is that the 1974 and 1975 predictions of the wage interdependence model are not generally as good as those of the simple structural model. Neither of them performs well, according to com-

28. In each of the autoregressive models, the wage changes in the current year are regressed on wage changes lagged one and two years. 
Table 4. Wage-Adjustment Regressions for Predictions,

\begin{tabular}{|c|c|c|c|c|c|c|}
\hline \multirow{3}{*}{$\begin{array}{l}\text { Type of wage, model, } \\
\text { and regression }\end{array}$} & \multirow[b]{3}{*}{ Constant } & \multirow{3}{*}{$\begin{array}{c}\text { Un- } \\
\text { employ- } \\
\text { ment } \\
\text { rateb } \\
U_{P}{ }^{-1}\end{array}$} & \multicolumn{4}{|r|}{ Variable } \\
\hline & & & \multicolumn{2}{|c|}{ Price change } & \multicolumn{2}{|c|}{ Wage differential } \\
\hline & & & $\dot{P}_{-1}$ & $\dot{P}_{-2}$ & $N U_{-1}$ & $N M_{-1}$ \\
\hline \multicolumn{7}{|l|}{ Current union } \\
\hline 1. Simple structural & $\begin{array}{c}-0.489 \\
(0.94)\end{array}$ & $\begin{array}{c}0.080 \\
(4.30)\end{array}$ & $\begin{array}{c}0.575 \\
(3.77)\end{array}$ & $\begin{array}{r}0.561 \\
(3.51)\end{array}$ & $\cdots$ & $\cdots$ \\
\hline $\begin{array}{l}\text { 2. Wage inter- } \\
\text { dependence }\end{array}$ & $\begin{array}{c}0.778 \\
(1.11)\end{array}$ & $\begin{array}{c}0.061 \\
(3.11)\end{array}$ & $\begin{array}{l}0.406 \\
(2.57)\end{array}$ & $\begin{array}{l}0.403 \\
(2.60)\end{array}$ & $\begin{array}{c}-0.281 \\
(2.17)\end{array}$ & $\begin{array}{c}-0.224 \\
(2.02)\end{array}$ \\
\hline $\begin{array}{l}\text { 3. Autoregressive } \\
\text { (union wages) }\end{array}$ & $\begin{array}{l}0.771 \\
(1.05)\end{array}$ & ... & $\ldots$ & $\ldots$ & $\ldots$ & $\cdots$ \\
\hline $\begin{array}{l}\text { 4. Autoregressive } \\
\text { (nonunion wages) }\end{array}$ & $\begin{array}{l}0.090 \\
(0.14)\end{array}$ & $\cdots$ & $\cdots$ & $\cdots$ & $\cdots$ & $\cdots$ \\
\hline \multicolumn{7}{|l|}{ Effective union } \\
\hline 5. Simple structural & $\begin{array}{l}1.502 \\
(2.62)\end{array}$ & $\begin{array}{l}0.018 \\
(0.87)\end{array}$ & $\begin{array}{l}0.666 \\
(7.33)\end{array}$ & $\ldots$ & $\ldots$ & .. \\
\hline $\begin{array}{l}\text { 6. Wage inter- } \\
\text { dependence }\end{array}$ & $\begin{array}{r}2.983 \\
(5.64)\end{array}$ & $\begin{array}{c}0.002 \\
(0.10)\end{array}$ & $\begin{array}{c}0.242 \\
(1.78)\end{array}$ & $\ldots$ & $\begin{array}{r}-0.397 \\
(3.78)\end{array}$ & $\begin{array}{c}-0.318 \\
(3.52)\end{array}$ \\
\hline $\begin{array}{l}\text { 7. Autoregressive } \\
\text { (union wages) }\end{array}$ & $\begin{array}{l}0.214 \\
(0.38)\end{array}$ & $\ldots$ & $\ldots$ & $\cdots$ & $\ldots$ & $\ldots$ \\
\hline $\begin{array}{l}\text { 8. Autoregressive } \\
\text { (nonunion wages) }\end{array}$ & $\begin{array}{l}0.712 \\
(1.81)\end{array}$ & $\cdots$ & $\cdots$ & $\cdots$ & $\cdots$ & $\cdots$ \\
\hline \multicolumn{7}{|l|}{ Nonunion } \\
\hline 9. Simple structural & $\begin{array}{r}5.060 \\
(8.50)\end{array}$ & $\begin{array}{l}-0.756^{\mathrm{b}} \\
(6.07)\end{array}$ & $\begin{array}{l}0.506 \\
(6.76)\end{array}$ & $\cdots$ & $\cdots$ & $\cdots$ \\
\hline 10. Autoregressive & $\begin{array}{l}0.435 \\
(0.70)\end{array}$ & $\ldots$ & $\ldots$ & $\cdots$ & $\cdots$ & $\cdots$ \\
\hline
\end{tabular}

Sources: See table 2.

a. For descriptions of the variables see notes to table 2. The numbers in parentheses are $t$-statistics.

b. The variable used for regression 9 is $U_{p}$; see table 2 , note $b$.

parisons with the 1975 predictions from the autoregressive models (see table 5). By rapidly incorporating the dampened responsiveness of union settlements to price inflation into their predictions-in other words, by not responding as fully to the CPI rises of $1973-74$ as the equations estimated through 1973 indicate they would-these models have yielded superior predictions of current union wage adjustments, particularly in $1975 . .^{29}$

29. In the general analysis of union and nonunion wage behavior over the 196075 period, experiments with autoregressive models in which current wage changes simply follow previous wage changes in their own sector or in a reference sector in- 
Union and Nonunion Manufacturing, 1960-73a

\begin{tabular}{|c|c|c|c|c|c|c|c|}
\hline \multirow{3}{*}{$\begin{array}{c}\text { Incomes- } \\
\text { policy } \\
\text { dummy } \\
\text { PHASE }\end{array}$} & \multicolumn{4}{|c|}{ Change in wages } & \multicolumn{3}{|c|}{ Summary statistic } \\
\hline & \multicolumn{2}{|c|}{ Union } & \multicolumn{2}{|c|}{ Nonunion } & \multirow[b]{2}{*}{$\bar{R}^{2}$} & \multirow{2}{*}{$\begin{array}{l}\text { Standard } \\
\text { error of } \\
\text { estimate }\end{array}$} & \multirow{2}{*}{$\begin{array}{l}\text { Durbin- } \\
\text { Watson }\end{array}$} \\
\hline & $\dot{W}_{-1}^{u}$ & $\dot{W}_{-2}^{u}$ & $\dot{W}_{-1}^{n}$ & $\dot{W}_{-2}^{n}$ & & & \\
\hline $\begin{array}{c}-0.461 \\
(1.14)\end{array}$ & $\cdots$ & $\cdots$ & $\cdots$ & $\cdots$ & 0.97 & 0.431 & 2.64 \\
\hline $\begin{array}{c}-1.921 \\
(2.28)\end{array}$ & $\ldots$ & $\ldots$ & $\ldots$ & $\ldots$ & 0.98 & 0.367 & 2.45 \\
\hline ... & $\begin{array}{r}0.869 \\
(3.37)\end{array}$ & $\begin{array}{c}-0.003 \\
(0.01)\end{array}$ & $\ldots$ & $\ldots$ & 0.76 & 1.080 & 1.85 \\
\hline$\cdots$ & ... & $\cdots$ & $\begin{array}{c}0.985 \\
(4.13)\end{array}$ & $\begin{array}{c}0.355 \\
(1.72)\end{array}$ & 0.85 & 0.838 & 2.09 \\
\hline $\begin{array}{c}1.458 \\
(3.58)\end{array}$ & $\ldots$ & $\ldots$ & $\ldots$ & $\ldots$ & 0.90 & 0.523 & 2.61 \\
\hline $\begin{array}{c}-0.927 \\
(1.23)\end{array}$ & $\ldots$ & $\ldots$ & $\ldots$ & $\ldots$ & 0.97 & 0.339 & 2.29 \\
\hline$\ldots$ & $\begin{array}{c}0.933 \\
(4.32)\end{array}$ & $\begin{array}{r}0.070 \\
(0.40)\end{array}$ & $\ldots$ & $\ldots$ & 0.82 & 0.654 & 1.99 \\
\hline$\cdots$ & $\cdots$ & ... & $\begin{array}{c}0.687 \\
(4.61)\end{array}$ & $\begin{array}{c}0.282 \\
(2.19)\end{array}$ & 0.87 & 0.525 & 2.41 \\
\hline $\begin{array}{c}1.430 \\
(4.32)\end{array}$ & $\ldots$ & $\ldots$ & $\ldots$ & $\ldots$ & 0.94 & 0.428 & 2.98 \\
\hline$\ldots$ & $\cdots$ & $\ldots$ & $\begin{array}{c}0.800 \\
(3.38)\end{array}$ & $\begin{array}{c}0.138 \\
(0.67)\end{array}$ & 0.74 & 0.834 & 1.75 \\
\hline
\end{tabular}

To summarize, this section has focused on differences between the wageadjustment process in the nonunion sector of manufacturing, typified by annual wage decisions, and the unionized sector, in which the wages of about 99 percent of the workers are specified in multiyear labor agreements. In some important respects the two sectors are similar, most notably in the influence of labor market pressure on current wage decisions. Nevertheless, average union wage changes are insulated from the current market pressures by the inertia imposed by multiyear contracts, and even the re-

dicated that their statistical properties were inferior to the structural models that were presented in table 2. 
Table 5. Actual and Predicted Wage Changes in Union and Nonunion Manufacturing, 1974 and 1975

Annual rate of change in percent; difference in percentage points

\begin{tabular}{|c|c|c|c|c|}
\hline \multirow[b]{2}{*}{ Type of wage and model } & \multicolumn{2}{|c|}{1974} & \multicolumn{2}{|c|}{1975} \\
\hline & Predicted & $\begin{array}{c}\text { Actual } \\
\text { minus } \\
\text { predicted }\end{array}$ & Predicted & $\begin{array}{c}\text { Actual } \\
\text { minus } \\
\text { predicted }\end{array}$ \\
\hline \multicolumn{5}{|l|}{ Current union } \\
\hline 1. Simple structural & 8.4 & -0.9 & 12.8 & -4.2 \\
\hline 2. Wage interdependence & 9.4 & -1.9 & 12.5 & -3.9 \\
\hline 3. Autoregressive & 5.7 & 1.8 & 7.3 & 1.3 \\
\hline 4. Autoregressive & & & & \\
\hline (nonunion wages) & 7.4 & 0.1 & 10.0 & -1.4 \\
\hline \multicolumn{5}{|l|}{ Effective union } \\
\hline 5. Simple structural & 7.8 & 0.2 & 9.9 & -1.9 \\
\hline 6. Wage interdependence & 5.1 & 2.9 & 6.0 & 2.0 \\
\hline $\begin{array}{l}\text { 7. Autoregressive } \\
\text { (union wages) }\end{array}$ & 6.4 & 1.6 & 8.1 & 0.1 \\
\hline $\begin{array}{l}\text { 8. Autoregressive } \\
\text { (nonunion wages) }\end{array}$ & 6.0 & 2.0 & 7.8 & 0.4 \\
\hline Nonunion & & & & \\
\hline 9. Simple structural & 6.4 & 1.6 & 6.6 & -0.3 \\
\hline 10. Autoregressive & 5.6 & 2.4 & 7.6 & -1.3 \\
\hline
\end{tabular}

Sources: See table 2. The predicted values are from the regressions in table 2 reestimated for 1960-73, and reported in table 4 . Line 1 here is derived from regression 1 in table 4 , line 2 from regression 2, and so on.

sponse of currently negotiated union wages to these pressures may be dampened by their response to important relative-wage relations. At the beginning of the seventies, disequilibria in their relative wages were quite large by postwar standards, and they have become an increasingly strong, although far from monolithic, influence on union-wage determination during the decade. Simultaneously, the direct influence of prices on contractual wages appears to have diminished in the latest years. The net result of these changes is that while the wage interdependence model appears to identify important influences on union wage determination, and to provide a superior explanation of union wage movements over particular historical periods, the importance of these influences has been shifting, altering the estimated structure of the wage relation and making its predictive performance inferior to that of simpler alternatives. For the nonunion sector, where wage determination appears uninfluenced by spillover pressures, such structural change has been negligible. 


\section{Wage Imitation among Major Collective Bargaining Agreements}

This section deals with the nature of wage interrelationships among major collective bargaining agreements. The notion that wage linkages within the organized sector are sufficiently strong that most unions and employers agree to "follow the pattern" grew out of a series of virtually identical wage rounds in the immediate postwar period, when most major unions renegotiated their contracts on an annual basis. In the intervening twentyfive years the contractual arrangements of the collective bargaining system have acquired sufficient diversity (for example, in duration of agreement and cost-of-living coverage) that maintaining such rigid patterns would be difficult even in the absence of differential market influences. Yet popular belief in the persistence of such patterns continues. ${ }^{30}$

Institutionally determined wage imitation is not proved by demonstrating that patterns of wage similarity exist in the economy. As noted earlier, many "wage patterns" would be expected in an economy without unions, and some institutional developments may simply codify practices and outcomes that would have been observed even in their absence. Although institutional codification and institutional rigidity are not always easy to distinguish, some of the more commonly cited "patterns" appear to fall within the former category.

Consider multi-employer negotiating arrangements. These represent a centralization of wage determination that would not exist in an unorganized labor market, and may influence the size of wage increases. At the same time multi-employer bargaining structures represent the ultimate codification of an interfirm wage pattern, and hence the ultimate potential for institutional wage rigidity. Where are they found? A key feature of U.S. collective bargaining arrangements is that centralized bargaining structures are found mainly in markets in which substantial variation in wage movements would be unlikely in the absence of unions. Where they are observed, they most frequently involve locally or regionally competitive product markets. In this sense they often represent the institutionalization of wage similarity that would have existed under competitive forces. Most multi-employer bargaining occurs outside of manufacturing; over 90 percent of unionized workers in construction, hotels and restaurants, whole-

30. A recent example: "What starts in the Big Three motor companies eventually percolates through most of the economy." A. H. Raskin, "Breakthrough on Work Hours," New York Times, October 8, 1976. 
sale trade, and trucking are covered by such agreements. In manufacturing they are most prevalent in the competitive apparel industry. By contrast, centralized bargaining structures are almost nonexistent in oligopolistic sectors of the economy. Less than 3 percent of the unionized workers in the primary metals, electrical machinery, nonelectrical machinery, transportation equipment, and utilities industries are covered by multi-employer agreements. ${ }^{31}$ This pattern reflects the costliness of enforcing a multi-employer bargain to prevent chiseling; and centralized negotiating arrangements tend to endure where the economic circumstances of the member firms are similar-that is, where the absence of the bargaining structure would have yielded substantial wage similarity anyway. ${ }^{32}$

A second demonstrable negotiated pattern appears in major oligopolistic industries in which collective bargaining takes place on a companywide basis. These intra-industry patterns describe settlements in, for example, the automobile, aerospace, meatpacking, and rubber industries. Here again, the similarity, if not the magnitude, of wage movements would be expected in the absence of unions. A major puzzle posed by negotiations in these industries is the absence of multi-employer bargaining. Current arrangements tend to weaken employer resistance by posing the threat of lost market shares during a strike while spreading union financial resources over a fraction of the union's industry-wide membership. ${ }^{.3}$

31. U.S. Bureau of Labor Statistics, Characteristics of Agreements Covering 1,000 Workers or More, July 1, 1973, Bulletin 1822 (Government Printing Office, 1974), p. 9.

32. For further discussion of relationships among bargaining structures, wage patterns, and wage levels in various industries, see Lloyd Ulman, "Cost-Push and Some Policy Alternatives," American Economic Review, vol. 62 (May 1972), pp. 245-46, and Lloyd Ulman, "Connective Bargaining and Competitive Bargaining," Scottish Journal of Political Economy, vol. 21 (June 1974), pp. 103-07.

33. This discussion leaves open the relationship between bargaining structure and wage inflation. Analyses of the effect of a multi-employer structure on wages do not yield unambiguous predictions (see references in note 32 ). Evidence on the issue is fragmentary and inconclusive. The only data I am aware of relating union wage increases to bargaining structure are presented below. The data come from Current Wage Developments, vol. 28 (April 1976), p. 44, and unpublished tabulations provided by the U.S. Bureau of Labor Statistics, Office of Wages and Industrial Relations; they describe the annual rate of change of wages over the life of all major union contracts negotiated in each of the three years and suggest (at most) that multi-employer settlements are not persistent wage leaders. 
The wage patterns described above are limited to domains in which market forces would also breed substantial similarity in wage changes. The subsequent analysis focuses on the extent to which these contracts interact to establish much broader patterns of wage imitation. The approach taken is similar to that in the previous section. Wage adjustments in prominent labor agreements in several major industries depend by hypothesis on the employment opportunities for union workers, past price changes, and the relative wage in other major contracts. Each of the collective bargaining situations studied yields settlements that are characteristic of the pattern followed within that industry, and regression analysis is used to test for wage interdependence among major collective bargaining agreements.

The analysis of individual contracts complicates the organization of the regression analysis. Observations should correspond to actual decisions, and in the present context the relevant decision is the settlement of negotiations over contract terms. By this measure, the interval between observations has changed over the postwar period as the duration of collective bargaining agreements has lengthened. This development forces choices concerning the appropriate definition of variables and greatly reduces the number of observations available for the analysis of each contract. Pooling the data from different contracts would obscure the channels of wage interdependence that are the focus of the study. In one important case, automobiles, the existence of multiyear contracts throughout the postwar period means too few observations for sensible regression analysis. (This does not, however, preclude tests of the effect of auto workers' wages on labor agreements in other industries.)

The specification of these regressions generally follows that of the preceding section, but now each observation is a contract agreement. The dependent variable is the average annual percentage change in the contractual wage rate over the life of the contract, and includes initial, deferred, and cost-of-living wage adjustments. The Bureau of Labor Statistics' Wage Chronology series, from which the data are gathered, evaluates the overall wage change in absolute terms, and generally provides a time series of wage-rate information only for selected occupations covered by each con-

\begin{tabular}{lccc}
\hline \multicolumn{1}{c}{ Bargaining structure } & 1973 & 1974 & 1975 \\
Multi-employer & 5.1 & 8.9 & 7.7 \\
Multiplant, single employer & 5.0 & 5.7 & 8.6 \\
Single plant, single employer & 5.9 & 6.7 & 7.7
\end{tabular}


tract. Therefore, the percentage change of wages of unskilled workers is used in the regression analysis.

Employment prospects of union members are represented by the average annual percentage change in employment of production workers over the life of the previous contract in the industry that corresponds most closely with the coverage of the contract. The rate of change of consumer prices is also measured as an annual average over the life of the previous contract. The specification is complicated by the intermittent presence of formulas for cost-of-living allowances in collective bargaining agreements. When a COLA arrangement is operative, contractual wage increases, as defined above, should be influenced by current, rather than past, price changes. Thus, when an existing contract included a COLA, the current price change was entered as an explanatory variable.

Two hypotheses concerning the nature of negotiated wage imitations were examined. The first was the target-relative-wage hypothesis advanced in the preceding section. The second assumed that unions seek to approximate recent settlements in other industries, irrespective of the current relative-wage position of the industries.

In the end, the tests for the effects of recent settlements were not successful and are not reported. The variables representing wage changes provided by recently concluded negotiations in other sectors were not significant and the signs on the coefficients varied from agreement to agreement. It may be that this hypothesis cannot be tested with available data. As one examines the postwar history of major collective bargaining relationships, it becomes clear that even if the hypothesis has merit, the resulting wage patterns may be too complex and too unstable from negotiation to negotiation to be captured adequately by regression analysis. As labor agreements of different durations have developed, negotiations in industry $i$ will first lead and then lag negotiations in industry $j$. A strike or a modest change in the expiration date of a labor agreement can also disturb a traditional leader-follower pattern.

The remaining discussion focuses on the target-relative-wage hypothesis. The relative-wage variables take the same form as in the preceding section with the exception that they now represent the proportional difference in the wage of unskilled workers in sectors $i$ and $j$ prior to negotiations in sector $i$. The influence of wages in the steel and auto industries relative to others is examined for each contract, since these are frequently asserted to be key bargains that set wage patterns for the economy. The 
effect of the generally growing differential in favor of the building trades is also examined for each contract. The other interactions tested were chosen on a more judgmental basis.

The results of the analysis of disequilibrium relative-wage influences among major union agreements are reported in table 6. Only the coefficients on the relative-wage variables appear in the table. Given the limited degrees of freedom available in a world of multiyear agreements, each coefficient was estimated from a separate regression in which the other variables included were the rates of change of prices and industry employment, as defined above. The performance of the unreported variables was mixed, with the expected positive coefficients on the employment and price-change variables attaining significance for only a minority of the bargaining relationships studied.

The role of the relative-wage disequilibria in major contract settlements is also uneven. While the point estimates reported in table 6 suggest that a falling wage relative to other unions will increase wage pressures in collective bargaining, few of the relationships are statistically significant and some coefficients are too small to be of economic significance. There is some evidence that relative-wage disequilibria are most influential across agreements negotiated by a single union (for example, the Steelworkers in steel and aluminum; the Automobile Workers in automobiles and aerospace), a finding that accords with discussions in the institutional literature. There are also some erratic channels of influence from union wages in the building trades.

My own view is that the results in this section are reasonably suggestive that relative-wage disequilibria play a significant role in wage determination in many collective bargaining relationships, and that the statistical significance of many of these influences will become clearer as the number of observations increases. However, this is quite different from the view that there are wage patterns that are so comprehensive and rigid that once a "key" negotiation is concluded, wage changes are essentially determined for major sectors of the organized economy. The evidence in tables 1 and 6 is consistent in indicating that this view is simply too strong. Indeed, many of the wage patterns that develop in collective bargaining appear rather fluid, with shifting channels of influence. One important topic for future work is the discovery of what influences such changes in the imitative patterns among unions. 


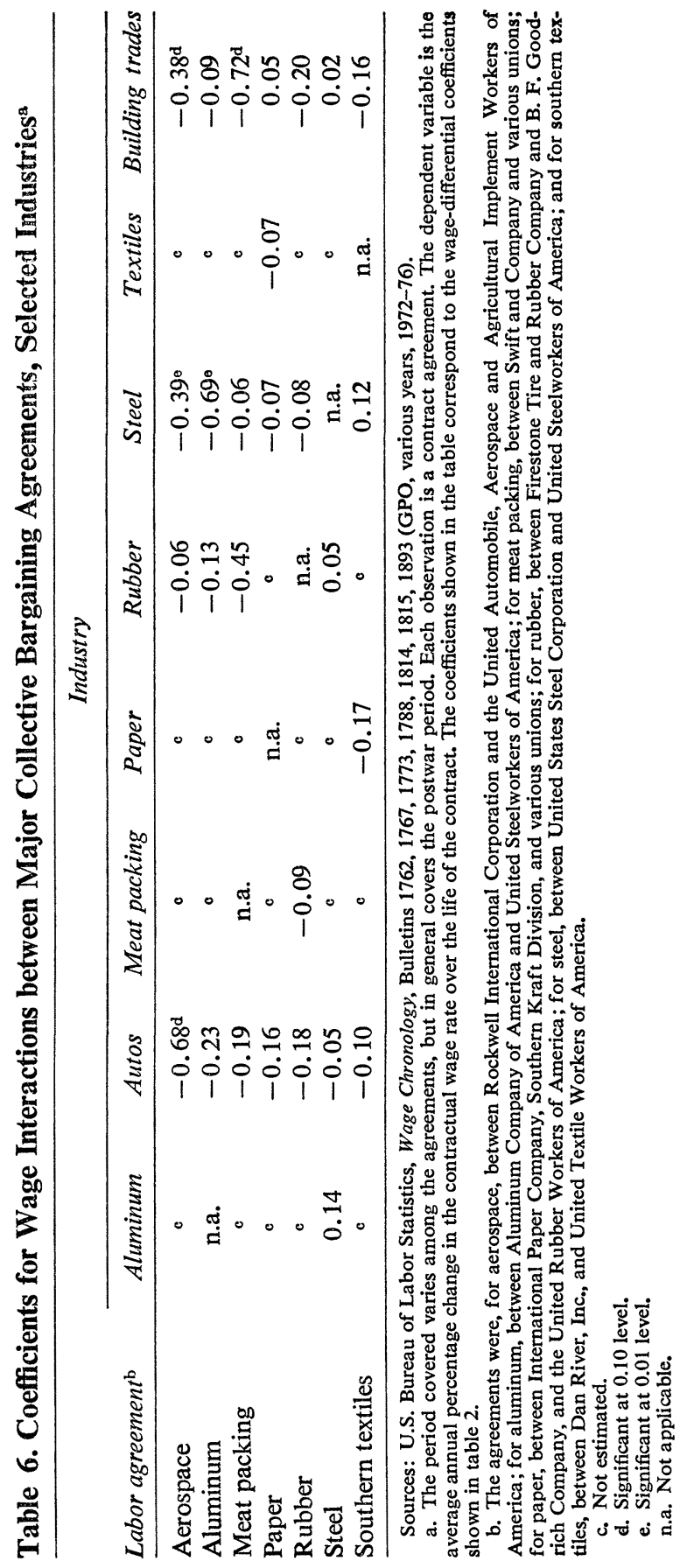




\section{Summary}

The focus of this paper has been the sources of differential wage flexibility in union and nonunion labor markets in manufacturing. That differences in the cyclical sensitivity of average union and nonunion wage changes exist is clear in the postwar data. However, it is also clear that firstyear negotiated wage changes are almost as sensitive to labor market pressure as nonunion wages. Most of the inertia in negotiated wages is a byproduct of multiyear labor agreements. In some periods, a disequilibrium between union wages in manufacturing and wages in the nonunion sector or in other unionized firms has been important in current negotiated wage decisions, muting the influence of the current labor market situation. Such relative-wage effects boosted union manufacturing settlements in the early seventies, and appear to have held them down in 1974-75, when rapid increases in the CPI led to predictions of union settlements even larger than those that occurred.

In general both the duration of labor agreements and relative-wage disequilibria may reduce the immediate influence of standard monetary and fiscal policies on money wages in parts of the organized sector. On the other hand, the importance of wage contagion is limited. The greatest impact of some highly visible collective bargaining settlements is on other agreements negotiated by the same union rather than on union wages more generally. Union wage movements in different industries vary considerably. And, more important, union wage gains do not appear to leak out into the nonunion sector where wages are lower and more flexible.

One consequence of labor markets with different degrees of wage flexibility is that a guideline approach to incomes policy may raise as well as lower wage increases when applied during a recession. Although the policy may succeed in reducing wages where they are least flexible, it may result in higher wage changes in the flexible-wage sector than otherwise would have been observed. The nonunion sector in 1972 and 1973 appears to be a case in point, with wages there rising faster than would have been expected on the basis of existing market conditions. This finding suggests that any direct policy interventions into labor markets should take full account of the differing wage flexibility in different markets, and the behavior of wages that would therefore be expected in the absence of such intervention. 


\section{Comments and Discussion}

Charles C. Holt: This paper probably offers the best explanation yet of the rather puzzling fluctuation in the union-nonunion wage differential. Earlier discussions of the topic usually stressed a simple dynamic lag in union wages, but this paper goes further both in modeling the way the differentials change cyclically and in determining their size in a steady state.

The basis for Flanagan's argument is his assertion that it is generally cheaper for a firm to maintain its relative position by imitating the wage changes of reference firms in relevant product and labor markets. Although this seems a reasonable proposition, I know of no body of theory or of evidence to support it, and I believe Flanagan should have given us a fuller treatment than he did.

Table 1 reports a striking change in the coefficient of variation of wage changes through time, whose sources pose a question. I think there is other evidence, over a longer period of time, that indicates that such changes are strongly cyclical. But the large reductions in the coefficient of variation from 1961 to 1975 for both the union and nonunion sectors suggest that they are structural; and the same could be said of the rising trend in the standard deviations. Finding such trends could be significant.

The basic theoretical specification for the union sector is stated in terms of wage differentials. This is an area that is undeveloped, both theoretically and empirically, and Flanagan is to be commended for having opened it up. Certainly, introducing a differential between the sector that he is examining and other reference sectors as an explanatory variable is a reasonable way to go. It might also be interesting to explore some other variables: One is the change in this differential. If the differential is actually getting wider it would have an even greater effect on bargaining behavior. This effect might be captured as a nonlinear trans- 
action term or explicitly as the change in the differential. Another is the change in wages of the reference group. Flanagan uses differences between two wage levels, but bargaining in the union sector may actually be strongly influenced by a big wage increase in the nonunion sector in the previous year.

Since the nonunion sector responds strongly to unemployment and general market conditions, putting nonunion wage changes as an explanatory variable into the union wage-change equation obviously imposes a strong collinearity problem; it might be better to use the deviation from the nonunion wage to try to sort out whether unemployment was having its impact directly on union bargaining, or indirectly through the nonunion sector.

Because of this collinearity problem, Flanagan restricts the number of these differentials in table 2. In effect, he puts them in one at a time, or at most two at a time. He shows that these differentials substantially reduce the residual error. One could look at $R^{2}$ and see if using all of the differentials helped at all. If it did, that would suggest a search for a theoretical and econometric specification for taking into account the multiple differential impacts.

Figure 1 shows the various differentials that are used as explanatory variables. It would have been interesting to plot these differentials weighted by their regression coefficients so as to see not only how the various explanatory variables move, but also how much each contributes to union wage changes.

In the comparisons of predictive performance in table 5 , it is disconcerting that in three out of the four cases for the union equations the autoregressive equations perform better than the basic model. This may be related to the need for an alternative specification that I suggested earlier. If the wage changes in the previous year in the nonunion sector do, in fact, heavily influence current collective bargaining, that might explain why these autoregressive equations perform as well as they do.

Flanagan does talk about the policy implications of his results as they relate to guidelines. The strong carryover effects that he finds from nonmanufacturing unions into the manufacturing sector certainly raise the question about what kind of intervention is called for. The very sharp leveling off of the differential for the construction industry apparently held down wages elsewhere as well; this effect ought to be called the "Dunlop-era impact." 
The policy implications with regard to the differential on an industryby-industry basis should be pursued further. For instance, since the competitive sector has a strong impact in establishing the nonunion differential which in turn influences union wages, improving the operation of the competitive sector through measures such as manpower programs ought to yield broad anti-inflation benefits.

In concentrating on the union-nonunion differential, Flanagan has omitted many important factors affecting industrial demand and labor supply. While his strategy certainly is understandable at this stage of the work, later refinements should include these factors.

Barry Bosworth: I believe that Bob Flanagan should be congratulated for writing a paper on wage behavior that is not another attempt to fit the aggregate measure of nonfarm compensation per manhour. This is an interesting paper that, by distinguishing between changes in negotiated and nonnegotiated wage rates, develops several significant hypotheses. I discovered several major themes from the study.

First, there is evidence of interdependence among union wage settlements, but no such spillover effects are apparent in the nonunion sector.

Second, the apparent lesser sensitivity to current market conditions of manufacturing union wage rates compared to nonunion wage rates is a result of multiyear contracting in the union sector; first-year settlements are responsive to labor markets just as nonunion wages are.

Third, the incorporation of a wage-wage view of the inflation process sharply reduces the estimated direct effect of prices on wages.

Fourth, wage-price controls or guidelines may put a floor under wage increases in some sectors at the same time that they restrain wages in others.

Fifth, all the structural models of union wages underpredict the increases of 1975.

Finally, there are no fixed leader-follower wage patterns in union settlements.

I would like to focus my comments, first, around the statistical results reported in tables 2 through 5 . The argument that current union settlements and nonunion wage changes are equally sensitive to market conditions is based on the nearly identical structure of equations 1 and 11 in table 2 . Equation 2 with a reciprocal of the unemployment rate is actually 
used as the basic structural equation for unions in later applications, but its statistical performance is similar to that of equation 1.

The results of table 5, however, show that the structural equations forecast a much different rate of wage increase for the union and nonunion sectors. From those results it appears that wage behavior is highly inflationary in the union sector compared to the nonunion sectors. Incidentally, the sharply higher predicted level of union settlements in recent years cannot be traced to imitative effects since equations with relative wages and the structural version of the equation forecast similar large increases in 1974 and 1975.

There are, I believe, two possible explanations for this result. First, the equations of tables 2 and 4, which are estimated for different periods, indicate somewhat different structures when the sample period is varied. Second, the use of the reciprocal of the unemployment rate in the unionsector predictions may cause a large difference in the projections for 1974-75 compared with the nonunion sector even if the equations are not so different over the sample period. This difference between the linear and nonlinear unemployment variables becomes important during periods like the 1970s, when the unemployment rate is changing sharply. For example, the rise in unemployment between 1973 and 1975 translates into a 1.4 percent reduction in current union wage settlements using the nonlinear version of equation 2 in table 2 compared with a 2.5 percent reduction using the linear form represented by equation 1 in that table.

All this leads me to wonder whether the equations for current wage adjustments are, in fact, stable enough functions to permit generalizations about the behavior of union wages. Certainly, on the basis of the results of table 4, one would not have concluded that union wages under new contracts respond to market conditions in a fashion similar to nonunion wages.

Flanagan's argument that wage guideposts under the Pay Board induced higher settlements in the nonunion sector is interesting but puzzling. How is it that this sector seems to be insensitive to spillover effects from the union sector, yet is sharply affected by a government announcement of a target? In addition, why was there no apparent effect in 1962-66 but a strong effect in 1972-73?

The distribution of these wage adjustments in 1972-73 reveals some interesting characteristics. First, median adjustments rose in 1972 relative 
to 1971 only because more workers got increases (83.2 versus 70.2 percent) rather than because increases that were obtained were larger (the median increase declined from 5.5 to 5.2 percent). In 1973, the median increase did rise to 6.0 percent, but the proportion receiving increases jumped again to an historical high of 90.1 percent.

The apparent acceleration of wage increases in the nonunion sector during the control period may revolve around merit increases, which are excluded from this wage series and which required special justifications under Pay Board procedures. In view of the very large rise in the proportion of workers receiving (general) increases, one explanation for Flanagan's result is that the controls program led many firms to shift from merit increases (which are not recorded in the data) to general increases.

An examination of the distribution of wage increases in 1971-73 supports the conclusion that controls reduced, not increased, wage changes. The frequency of increases of less than 4 percent actually rose in 1972 and the frequency of increases of more than 6 percent declined sharply. Thus the controls worked to pull down large increases without reducing the frequency of small increases. As I already noted, the median increase declined from 5.5 to 5.2 percent. Thus Flanagan's argument is not supported in 1972.

However, in 1973 the frequency of increases below 4 percent declined sharply-supporting Flanagan's argument. But the frequency of settlements in the 4-6 percent range also declined. The rise in the median settlement is accounted for by a sharp expansion in the proportion receiving increases above 6 percent-particularly above 12 percent. Thus the median rose primarily because of a sharp rise in the number of apparent violators. It seems that wages rose as fast as they did in 1973 because the wage standard was frequently ignored, not because it pulled up wages that would have risen more modestly in its absence.

Given the problems of interpreting the rise in the proportion of workers receiving general increases and the changing distribution of the increases, I think Flanagan's conclusion on the result of wage controls is rather strong.

Robert J. Flanagan: Barry Bosworth notes correctly that the evidence indicates that the structure of the wage-adjustment process in the organized sector has changed during the seventies. This is hardly a surprise, in light of previous experience with models of the rate of change of earn- 
ings or total compensation. The novelty of the results is in the stability of the nonunion sector; the sources of instability in more aggregated wage equations are apparently to be found in the organized sector.

Bosworth also discusses the distribution of nonunion wage changes during 1972 and 1973. I find the distribution data interesting, but hard to interpret without a model of what would have been expected in the absence of the incomes policy. If the policy is stimulated by a concern with the average rate of money-wage changes and one effect of the policy is to increase the number of firms paying positive increases, this effect should be considered in assessing the impact of the policy.

Charles Holt suggested as an alternative to the target-relative-wage hypothesis in the paper that differences in the rate of change of wages in sectors $i$ and $j$ may influence wage changes in sector $i$. I tested for this mechanism while preparing the paper but found little empirical support for it.

\section{General Discussion}

A good deal of discussion centered around the proper interpretation of relative-wage variables in the union-wage regressions. Robert Hall and several others felt that, rather than implying that imitative effects linked manufacturing union with nonunion (and other union) wages, the regressions might reflect simply the less responsive nature of manufacturing union wages resulting from the three-year bargaining cycle. On this interpretation, what appears to be a response by the unionized sector to the wage differential between the sectors is actually a delayed market response to the original cause of the movement in the nonunionized sector's wages. Hall stressed that this alternative interpretation had very different policy implications; for instance, some intervention in nonunion wages would not influence union wages. Flanagan disagreed with this interpretation in part because the relative-wage influence is discerned even when sectorspecific labor market variables are used in the regression analysis, but, more important, because of the direction of the relative-wage influence: wages in the high-wage unionized sector respond to relative-wage "disequilibria," but wages in the low-wage nonunionized sector do not. If the relative-wage variable were merely a proxy for quit-rate pressures on employers, one would expect it to have a significant influence on wage deter- 
mination in the nonunionized sector. He also noted that lagged unemployment and inflation variables had not displaced the relative-wage variables in regressions and that the lagged unemployment variables had always been statistically insignificant.

William Poole reasoned that the relative-wage terms could be serving as proxies for price expectations, filling this purpose better than the lagged price terms that were also tried in the equation. Other discussants suggested alternative explanatory variables that might establish whether the relative-wage terms truly represented imitative effects or were proxies for other effects. Christopher Sims, noting that the autoregressive equations have performed relatively well in projecting wage changes, argued for exploring that type of model along with the relative-wage terms in order to pin down the structural role of the latter.

Martin Feldstein was concerned that the dependent variable might be misspecified since current wage changes omitted increases arising from cost-of-living allowances, fringe benefits, and merit pay increases. Robert Gordon voiced surprise that Flanagan's reported price coefficients were small enough that the Phillips curve had a substantial negative slope in the long run, contrary to his own and others' recent research findings. $\mathrm{He}$ noted that the price coefficients might be biased downward both by the omissions Feldstein had pointed out in the dependent variable and by the use of the consumer price index as an independent variable rather than a measure of producer prices. The latter effect would be particularly noticeable in 1974 and 1975, when increases in import and food prices were so large and were never fully incorporated into wages. He pointed out that wage equations would overpredict in 1974 and 1975, as Flanagan's do, if the CPI were indeed not the structurally appropriate price variable.

Franco Modigliani was skeptical about the conclusion that the union and nonunion sectors were comparably responsive both to labor market conditions and to inflation. In his own research, he had found that, compared to nonunion wages, union wages were more responsive to inflation and less responsive to unemployment. He noted that the equations Flanagan fitted through 1973 also showed this characteristic.

Regarding his choice of dependent variables, Flanagan emphasized that the paper seeks to explain the behavior of contractual rates in the union and nonunion sectors and therefore the results would not necessarily be expected to parallel findings from studies of earnings or total compensation. Indeed, a comparison of studies based on these alternative wage 
concepts provides some clues to the behavior and role of wage drift in the economy. The present regression results on contractual settlements indicate that workers are fooled in their contractual negotiations, and data on the different gains of workers with and without COLA provisions in their contracts do not overturn this perception. The behavior of wage drift, which links contractual wages to actual earnings, is strongly related to price inflation and may reconcile this paper with studies of earnings that identify a natural unemployment rate. 